Kanserli Çocuklarda Oral Mukozit İçin Kullanılan Kanıta Dayalı

Yöntemler: Sistematik Derleme

\title{
Evidence Based Methods for Oral Mucositis in Children with Cancer:
}

Zeynep Osmanoğlu Yurdakul ${ }^{1}$, Figen Işık Esenay ${ }^{2}$

${ }^{1}$ Dr. Abdurrahman Yurtaslan Onkoloji Eğitim ve Araştırma Hastanesi, Ankara, Türkiye

${ }^{2}$ Ankara Üniversitesi, Sağlık Bilimleri Fakültesi, Ankara, Türkiye

\section{$\ddot{O} Z$}

GIRIŞ ve AMAÇ: Bu çalışma, kanserli çocuklarda gelişen oral mukozitin (OM) önlenmesi ve tedavi edilmesi için kanıta dayalı uygulamaların kullanıldığı araştırmaların incelenmesi amacıyla yapılmıştır. YÖNTEM ve GEREÇLER: Taramalar Ankara Üniversitesi Kütüphane ve Dökümantasyon Daire Başkanlığı'nın veri tabanları (Medline, OVID, EBSECOhost, Science Direct, Ulakbim Ulusal Veri Tabanları) üzerinden Ağustos 2017- Şubat 2018 tarihleri arasında yapılmış, araştırmalar hemşirelik ve sağlık bakım hizmetlerinde kanıt temelli uygulama rehberi kanıt listesi kullanılarak değerlendirilmiştir.

BULGULAR: Kanserli çocuklarda OM'nin önlenmesi ve tedavisinde kullanılan 14 farklı yöntemi inceleyen 32 çalışmaya rastlanmış ve bu çalışmaların \%62,5'inin randomize kontrollü, \%21,8'inin ise randomizasyonun olmadığı deney kontrollü yöntemle yapıldığı saptanmıştır. İncelenen makalelerin, çoğunda kullanılan yöntemlerin OM semptomlarının yönetiminde etkili olduğu bulunmuş, bazı yöntemlerin çalışma sonuçlarının birbirini desteklemediği görülmüştür.

TARTIŞMA ve SONUÇ: Kanserli çocuklarda gelişen OM'nin önlenmesi ve tedavi edilmesi için çok sayıda yöntem kullanılmaktadır. Ancak, kanıt oluşturacak çalışma sayısının az olması ve kanıtların tutarsız olması OM için standart bir ağız bakım protokolü oluş̧turulmasını engellemektedir.

Anahtar Kelimeler: Çocukluk çağı kanserleri, geleneksel ve tamamlayıcı tedaviler, kanıta dayalı uygulamalar, kanserli çocuklarda oral mukozit, oral mukozit 


\section{SUMMARY}

INTRODUCTION: This study aims to investigate the studies using evidence based practice for the prevention and treatment of oral mucositis $(\mathrm{OM})$ in children with cancer.

METHODS: Literature searches were conducted between August 2017 and February 2018 through the databases of the University of Ankara Library and Documentation Department (Medline, OVID, EBSECOhost, Science Direct, Ulakbim National Databases). Studies were evaluated using the evidence-based practice in nursing and healthcare: a guide to best practice.

RESULTS: There were 14 different methods for prevention and treatment of OM in children with cancer. $62.5 \%$ of them were randomized controlled studies and $21.8 \%$ not randomized experimental studies. Methods have been found to be effective in symptom management in most of the examined articles, but some methods have been found incosistent.

DISCUSSION and CONCLUSION: Numerous methods are used for the prevention and treatment of OM in children with cancer. However, the limited number of the studies and inconsistency of the results prevents the establishment of a standard oral care protocol for OM.

Keywords: Childhood cancers, evidence-based practices, oral mucositis, oral mucositis in child with cancer, traditional and complementary treatments 


\section{Giriş}

İnsanoğlu yüzyıllardır doğayla iç içe yaşamış, çevrelerinde ulaşabildikleri bitkileri tedavi amaçlı kullanmıştır. Zamanla deneme, yanılma ve izleme yoluyla etkisi değerlendirilen bitkilerin kullanımı, bölgelerin kültürel uygulamaları olarak yerleşmiştir (1). Bu uygulamalar, başta kanser olmak üzere bir çok hastalık ve semptomun giderilmesinde, tek başına ya da tıbbi tedaviyle birlikte uzun yıllardır toplum tarafından kullanılmaktadır. Modern tıp dışında kullanılan bu yöntemler Sağlık Bakanlığı’nın 27.10.2014 tarihli yönetmeliğinde "geleneksel ve tamamlayıcı tedaviler" olarak tanımlanmıştır (2). Türkiye'de en yaygın kullanılan geleneksel ve tamamlayıcı tedavi yöntemleri bitkisel ürünlerdir (3-5). Dünya genelinde çocuklarda geleneksel ve tamamlayıcı uygulama kullanımının \%10,9-87,6 (6,7), kanserli çocuklarda ise bu oranın \%6-100 arasında değiştiği bildirilmektedir (8). Türkiye'deki çocuklarda geleneksel ve tamamlayıcı uygulama kullanımı \%26-87 iken (9) kanserli çocuklarda bu uygulamaların kullanım sıklığı \%48,9-97,3 olarak belirlenmiştir $(3-5,10)$. Literatürde, geleneksel ve tamamlayıcı tedavi kullanımının sağlık personeline bildirilme oranının \%25-75 $(3,4,11)$ olduğu görülmektedir. Kanıta dayalı uygulamalar bilimsel verilerin hastaların yararına kullanılmasını esas almaktadır (12). Ancak ebeveynlerin kullandıkları yöntemlerin ve yan etkilerinin bilinmemesi, sağlık personelinin kanıta dayalı uygulama yapmasını engelleyen bir durumdur.

Ebeveynler, kanserli çocukları için mümkün olan herşeyi yapmak istemeleri nedeniyle geleneksel ve tamamlayıcı yöntemlerden vazgeçememekte (8), çocukluk çağı kanser tedavisinin en sık karşılaşılan yan etkisi oral mukozit (OM) (\%40-100) (13) için de sıklıkla bu yöntemleri kullanmaktadır. Oncology Nursing Society OM için kullanılan yöntemleri etkinliklerine ve kullanım amaçlarına göre sınıflandırmıştır (14), ancak kanıtların çoğu erişkin hastalara yöneliktir. Bu makalede, pediatrik onkoloji literatürü sistematik olarak incelenerek, kanserli çocuklarda OM için kullanılan yöntemlerin kanıt düzeyleri hakkında bir kaynak sağlanması amaçlanmıştır.

Araştırma soruları: 1) Pediatrik hematoloji onkoloji hastalarında OM için kullanılan hangi yöntemler için kanıt çalışmaları vardır?

2) Bu çalışmalara göre, pediatrik hematoloji onkoloji hastalarında kullanılan yöntemlerin OM üzerine etkisi nedir? 


\section{Gereç ve Yöntem}

$\mathrm{Bu}$ araştırmada, konuyla ilgili makaleler geriye dönük sistematik olarak taranmış ve döküman analizi yapılmıştır. Bu amaçla Ankara Üniversitesi Kütüphane ve Dökümantasyon Daire Başkanlığı'nın veri tabanları (Medline, OVID, EBSECOhost, Science Direct, Ulakbim Ulusal Veri Tabanları) üzerinden Ağustos 2017- Şubat 2018 tarihleri arasında taramalar yapılmıştır. Çalışmalarda araştırma basamak süreçleri olan "Sorun (Problem), müdahale (Intervention), karşlaştırma (Comparison), sonuç (Outcome), çalışma tasarımı (Study design) PICOS” basamakları dikkate alınmıştır. Türkçe veri tabanları için; "Çocukluk çağı kanserleri”, "Geleneksel ve tamamlayıcı tedaviler", "Kanıta dayalı uygulamalar", "Kanserli çocukta oral mukozit", "Oral mukozit", ingilizce veri tabanları için; "Oral mucositis in child with cancer ", "Childhood cancers", "Evidence-based practices", "Oral mucositis", "Traditional and complementary treatments" anahtar kelimeleri kullanılmıştır. Kullanılan anahtar kelimelerin kombinasyonları aşağıda sunulmuştur:

1. Çocukluk çağı kanserleri ve oral mukozit

2. Geleneksel ve tamamlayıc tedaviler ve oral mukozit

3. Kanıta dayalı uygulamalar ve kanserli çocukta oral mukozit

Makale Seçim Kriterleri:

Çalışmaya dahil edilen makalelerin seçiminde aşağıda sunulan kriterler dikkate alınmıştır;

- Yayın dilinin Türkçe ya da İngilizce olması,

- Orjinal ve kantitatif nitelikte bir araştırma makalesi olmas1,

- Sorun, müdahale, karşılaştırma, sonuç ve çalışma tasarımı (PICOS) basamaklarının bulunmas1,

- Tam metine ulaşılması,

- Çalışma örnekleminde çocukluk çağı kanser tanısı almış hastaların olması,

- Kongre bildirilerinin çalışma dışında tutulması dikkate alınmıştır.

Çalışmaların Seçimi ve Verilerin Analizi: Seçilen uygun veri tabanları kullanılarak anahtar kelimeler belirtilen kombinasyonlarla veri tabanlarına girilmiş ve tarama sonuçları kayıt edilmiştir. Tarama sonucu 96 makale listelenmiş, benzer çalışmalar ayırıldığında 74 çalışma belirlenmiştir. Belirlenen 
araştırmaların başlık ve özetleri incelenmiş, seçme kriterlerine uymayan (pediatrik popülasyonda yapılmamış, tam metin olmayan ve PICOS basamaklarına uymayan) 42 makale değerlendirme dışı bırakılmış, 32 makale değerlendirmeye alınmıştır.

Seçilen araştırmalar, pediatrik onkoloji hemşireliğinde uzman iki hemşire akademisyen tarafından, hemşirelik ve sağlık bakım hizmetlerinde kanıt temelli uygulama rehberi kanıt listesi (15) kullanılarak değerlendirilmiştir (Tablo 1). Bağımsız olarak yapılan değerlendirmeler karşılaştırılmış ve farklı görüşte olunan durumlar hakkında ortak bir karara varılmıştır.

Tablo 1. Hemşirelik ve sağlık bakım hizmetlerinde kanıt temelli uygulama rehberi kanıt listesi

\begin{tabular}{|c|c|c|}
\hline KANIT TİPİ & $\begin{array}{l}\text { KANIT } \\
\text { DÜZEYİ }\end{array}$ & AÇIKLAMA \\
\hline $\begin{array}{l}\text { Sistematik inceleme veya } \\
\text { meta-analiz }\end{array}$ & I & $\begin{array}{l}\text { İlgili tüm randomize kontrollü çalışmalardan elde edilen } \\
\text { kanıtların bir sentezi. }\end{array}$ \\
\hline $\begin{array}{l}\text { Randomize kontrollü } \\
\text { çalışma }\end{array}$ & II & $\begin{array}{l}\text { Deneklerin bir tedavi grubuna veya kontrol grubuna } \\
\text { randomize edildiği bir deney. }\end{array}$ \\
\hline $\begin{array}{l}\text { Randomizasyon olmadan } \\
\text { kontrollü çalışma }\end{array}$ & III & $\begin{array}{l}\text { Deneklerin bir tedavi grubuna veya kontrol grubuna } \\
\text { randomize olmayan bir şekilde tayin edildiği bir deney. }\end{array}$ \\
\hline $\begin{array}{l}\text { Vaka-kontrol veya khort } \\
\text { çalışması }\end{array}$ & IV & $\begin{array}{l}\text { Vaka-kontrol çalışması: Koşulu öngörebilen özellikleri } \\
\text { belirlemek için koşulu olmayanlar ile koşulu olan } \\
\text { olguların karşılaştırılması. Kohort çalışması: Bir hastalık } \\
\text { gibi bir sonucun gelişimini belirlemek için grupların } \\
\text { gözlemi. }\end{array}$ \\
\hline $\begin{array}{lr}\text { Kalitatif veya } & \text { tanımlayıcı } \\
\text { çalışmaların } & \text { sistematik } \\
\text { olarak gözden geçirilmesi }\end{array}$ & $\mathrm{V}$ & $\begin{array}{l}\text { Bir klinik soruyu cevaplamak için nitel ya da tanımlayıcı } \\
\text { çalışmalardan elde edilen kanıtların bir sentezi. }\end{array}$ \\
\hline $\begin{array}{l}\text { Kalitatif veya tanımlayıcı } \\
\text { çalışma }\end{array}$ & VI & $\begin{array}{l}\text { Niteliksel çalışma: Kararların neden ve nasıl yapıldığını } \\
\text { anlamak için insan davranışları hakkında veri toplar. } \\
\text { Tanımlayıcı çalışma: Çalışmanın ne araştırdığını, nerede } \\
\text { ve ne zaman yapıldığı hakkında arka plan bilgisi sağlar. }\end{array}$ \\
\hline $\begin{array}{l}\text { Uzman görüşü veya } \\
\text { konsensüs }\end{array}$ & VII & Uzman komitesinin yetkili görüşü. \\
\hline
\end{tabular}

Kaynak: Fineout-Overholt ve ark., 2010 


\section{Bulgular}

Kanserli çocuklarda OM önlenmesi ve tedavisi için kullanılan yöntemler hakkındaki araştırmalar tarandığında, 2001-2018 arasında yapılmış toplamda 74 çalışmaya ulaşılmış ancak 32 çalışma değerlendirmeye alınmıştır. Taranan çalışmaların dahil edilmeme nedenleri Şekil 1'de sunulmuştur. İncelenen çalışmaların büyük kısmının randomize kontrollü çalışma olduğu görülmüştür. Araştırmacıların büyük çoğunluğu tarafından OM'yi değerlendirmek için Dünya Sağlık Örgütü (DSÖ) OM skalası ve ulusal kanser enstütüsü yaygın toksisite kriterlerinin (national cancer ınstitutecommon toxicity criteria/NCI-CTC) kullanıldığı belirlenmiştir.

Şekil 1. Uygulama Akış Şeması

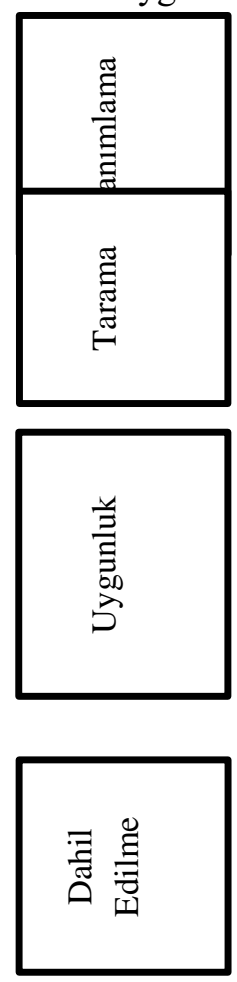

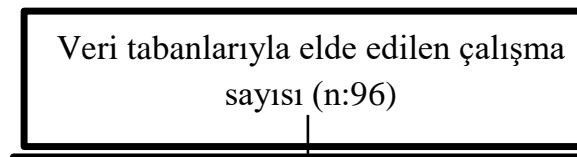

Dublike çalışmaların çıkarılması (n:74)

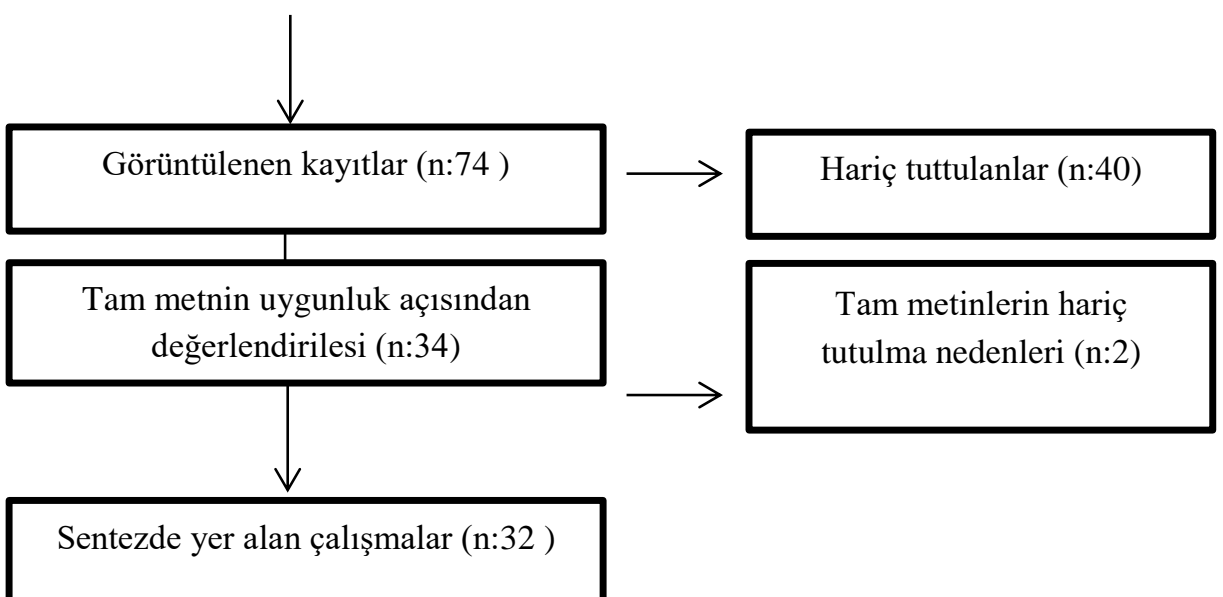


Yapılan çalışmaların düşük yoğunluklu lazer tedavisi (DYLT) (6 çalışma), klorheksidin (4 çalışma), palifermin (4 çalışma), bal (3 çalışma), E vitamini (3 çalışma), gulutamin (2 çalışma), benzidamin (2 çalışma), kriyoterapi (2 çalışma), sakız (2 çalışma), Traumeel S (2 çalışma), propolis (1 çalışma), gronülosit makrofaj koloni stimülan faktörü (rhGM-CSF ) (1 çalışma), yüksek yoğunluklu lazer tedavisi (YYLT) (1 çalışma) ve caphasol (1 çalışma) kullanımının OM üzerine etkinliğini kanıtlamaya yönelik yapıldığı görülmüştür. Çalışmalarda kullanılan yöntemler;

-Düşük Yoğunluklu Lazer Teadavisi (DYLT): Lazer tedavisi kronik iyileşmeyen yaralarda analjezik ve antienflamatuar $(\lambda=630-650 \mathrm{~nm}$ ve $780-900 \mathrm{~nm})$ özelliklerinden dolayı kullanılmaktadır. Düşük doz lazer, kollajen sentezini uyarmakta ve oral mukozada hücre proliferasyonunu sağlayarak epitelizasyonu arttırmaktadır. Düşük yoğunlukta uygulanan lazer tedavisi, mukozitin önlenmesinde ve tedavisinde kullanılmaktadır (16-21).

-Klorheksdin: Geniş spektrumlu, antimikrobiyal ve antiseptik özellikteki klorheksidin topikal uygulanarak bakteri ve mantarlar üzerinde etkili olmaktadır (22-25).

-Palifermin: Mezenkimal hücreler tarafından üretilen ve FGFR2b reseptör aracıllı̆̆ıla hücresel tepkileri uyaran 28-kD proteinidir (26). Proinflamatuar sitokin sayısını azaltarak serbest radikallerin sayısını arttırmakta ve epitel hücrelerinin gelişimini uyarmaktadır (27-30).

-Bal: pH değeri 3,20-4,50 arasında olan bal asidik bir ortam oluşturarak bakteri kolonizasyonunu önlemektedir. Polifenol içeriğinden dolayı antioksidan özelliktedir ve antienflamatuar etki göstermektedir (31-33).

-Vitamin E: Yağda çözünebilen antioksidan özellikteki E vitamini serbest radikallerin neden olduğu hücre hasarının önlenmesinde etkilidir (34-36).

-Glutamin: Vücutta en fazla bulunan serbest aminoasit olarak, katabolik stres durumunda hücrenin mitoz bölünmesi, protein sentezinin yapılması, mukozal hücre bütünlüğünün ve bağırsak bariyer fonksiyonunun korunması için gerekmektedir (37-38).

-Benzidamin: Lokal analjezik, anestetik, anti-inflamatuar ve antimikrobiyal özelliktedir. Gargara yapılmas1 ve yutulmamas1 gerekmektedir (12). 
-Kriyoterapi: Antineoplastik ajanların uygulanması sırasında ağız içine alınan buz küplerinin/parçacıklarının oral kavitede vazokonstrüksiyona neden olarak kan akımını yavaşlatması, mukoza hasarını azaltmaktadır $(39,40)$.

-Sakız: Tükürük salgısı antimikrobiyal ve mukoza koruyucu bileşenleri içermekte ve azalması oral kavitenin zarar görmesine neden olmaktadır. Sakız çiğnemek, tükürük salgısını arttırmakta, oral kaviteyi temizleyerek korumaktadır $(41,42)$.

-Traumeel S: Düşük konsantrasyonlarda 14 çeşit medikal amaçla kullanılan bitki ve mineralden oluşmaktadır. 50 yıldır geleneksel olarak kullanılan antienflamauar bir ilaçtır $(43,44)$.

-Propolis: Bal arılarının bitkilerden topladığı doğal bir üründür, bakterilere ve fungal mikroorganizmalara karşı antibakteriyel ve antienflamatuar özellikte olup antiülser ve antitümör aktiviteye sahiptir. Propolis folinollerinin içerdiği antioksidanlar serbest radikal oluşum sürecine dahil olarak reaksiyonun akışıı bozmakta ve oksidatif reaksiyonları azaltmaktadır $(31,45,46)$.

-Granülosit Makrofaj Koloni Stimülan Faktör (GMCSF): Kemik iliğini uyararak nötrofil, bazofil, eozinofil ve makrofajların üretilmesini sağlamaktadır $(14,47)$.

-Yüksek Yoğunluklu Lazer Tedavisi (YYLT): Dalga boyu ve enerjisi DDLT’ne göre daha yüksektir (48).

-Caphosol (Kalsiyum Fosfat Gargara): Yapısının tükürüğe benzemesinden dolayı oral kavitenin normal iyon $\left(\mathrm{Ca}^{+2}\right.$ ve $\left.\mathrm{PO}_{4}^{-3}\right)$ ve $\mathrm{pH}$ değerini korumaya yardımcı olmaktadır. Oral kavitenin temizliğinde ve nemlendirilmesinde etkindir $(49,50)$.

İncelenen çalışmaların yazarları, yapıldığı yıl, araştırmanın türü, örneklemin özellikleri, ölçüm araçları, kullanılan yöntemin uygulaması, elde edilen önemli bulgular ve kanıt düzeyleri Tablo 2'de sunulmuştur. 
Yurdakul 0.2 ve ark. Kanserli çocuklarda Oral Mukozit

JCP2018;16(3):51-78

Tablo 2. Kanserli çocuklarda oral mukozite yönelik kullanılan kantta dayal yöntemler

\begin{tabular}{|c|c|c|c|c|c|}
\hline $\begin{array}{l}\text { Yazarlar } \\
\end{array}$ & Araştırma Türü/ Örneklemi & Ölçüm Aracı & Uygulama & Elde edilen sonuç & $\begin{array}{l}\text { Kanit } \\
\text { düzeyi }\end{array}$ \\
\hline $\begin{array}{l}\text { Kuhn ve ark. } \\
2009\end{array}$ & $\begin{array}{l}\text {-Tek merkezli randomize kontrollü } \\
\text { çalışma } \\
\text {-Kemoterapi alan veya hematopoetik } \\
\text { kök hücre nakli olan, Evre II OM'li } \\
\text { hastalar (n=21;3-18 yaş) }\end{array}$ & -NCI-CTC & $\begin{array}{l}\text {-DYLT uygulanan gruba ( } \mathrm{n}=9) \text { OM tanısı konulduktan } \\
\text { lezyonları tam iyileşmesine kadar ( } 5 \text { ardşsıık gün) lazer } \\
\text { tedavisi ( } \lambda=830 \mathrm{~nm} \text { ) uygulanmıştr. } \\
\text {-Kontrol grubuna ( } \mathrm{n}=12) \\
\text { placebo (lazer kapalı olarak) uygulaması yapıılmıştr. }\end{array}$ & $\begin{array}{l}\text {-Lazer tedavisi uygulanan grupta bir kişide, kontrol grubunda dokuz kişide Evre II ve } \\
\text { üzeri OM görülmüş̧ür ( } \mathrm{p}=0,029) \text {. } \\
\text {-Lazer tedavisi uygulanan grupta OM iyileşme süresi ortalama olarak } 5,8 \pm 2,0 \text { gün, } \\
\text { kontrol grubunda ise } 8,9 \pm 2,4 \text { gün olarak belirtilmiş̧ir ( } \mathrm{p}=0,004) \text {. } \\
\text {-Lazer tedavisinin OM'nin iyileşmesinde hızlanma sağladı̆ğ saptanmıştr. }\end{array}$ & II \\
\hline $\begin{array}{l}\text { Cauwels ve } \\
\text { Martens } 2011\end{array}$ & $\begin{array}{l}\text {-Tek merkezli prospektif gözlemsel } \\
\text { calışma } \\
\text {-Kemoterapi alan hastalar }(\mathrm{n}=16 \text {, } \\
\text { ortalama 9,4 yas })\end{array}$ & -DSÖ OM skalası & $\begin{array}{l}\text {-Tüm hastalar (n=16) } 2 \times 1 \text { diş firçalama ve } \% 0,05 \\
\text { klorheksidin gargara kullanmıștr. } \\
\text {-OM geliş̧tikten iyileşme sağlanana kadar } 48 \text { saate bir } \\
(\lambda=830 \mathrm{~nm} \text { ) kızı ötesi lazer uygulanmıștrr. }\end{array}$ & $\begin{array}{l}\text {-Ortalama olarak haftada bir } 2,5 \text { seans tedavi sonrassnda OM lezyonlarınn iyilestiği } \\
\text { belirtilmiştir. }\end{array}$ & VI \\
\hline $\begin{array}{l}\text { Castro ve } \\
\text { ark. } 2013\end{array}$ & $\begin{array}{l}\text {-Tek merkezli randominizasyonun } \\
\text { olmadı̆ı̆ deney kontrollü çalışsma } \\
\text {-Yüksek doz metotreksat alan akut } \\
\text { lenfoblastik lösemi tanınlı hastalar (n=40, } \\
\text { 1-18 yaş) }\end{array}$ & $\begin{array}{l}\text {-DSÖ OM skalası } \\
\text {-VAS }\end{array}$ & 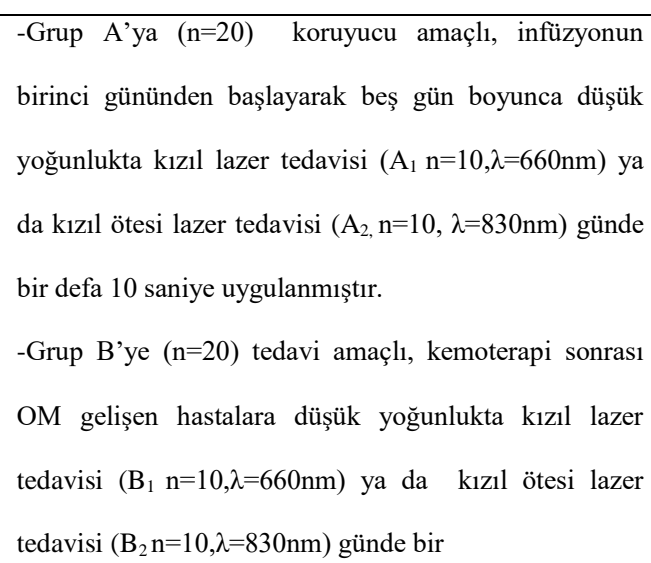 & 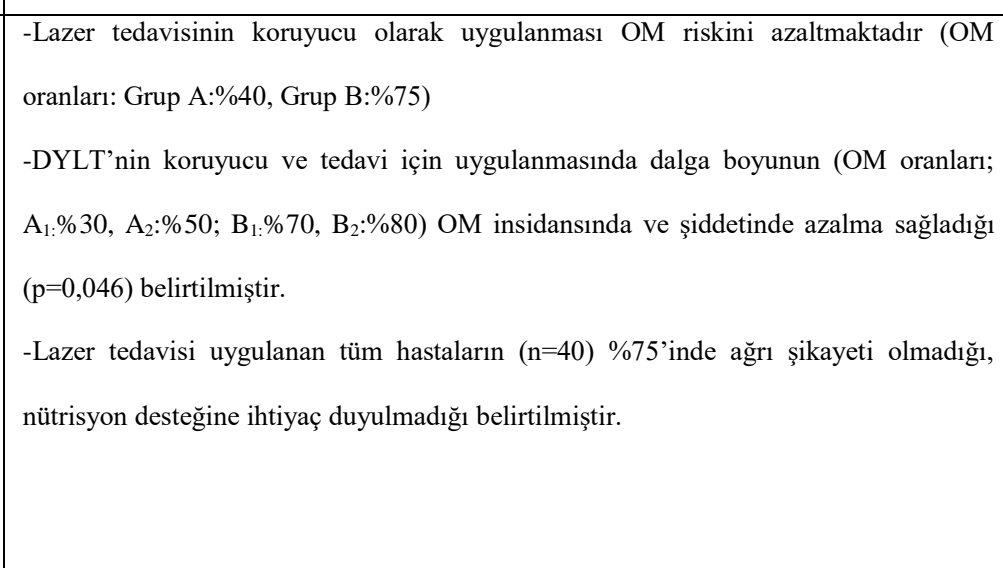 & IIII \\
\hline
\end{tabular}


Yurdakul 0.2 ve ark. Kanserli çocuklarda Oral Mukozit

JCP2018;16(3):51-78

Tablo 2. Devam. Kanserli çocuklarda oral mukozite yönelik kullanılan kantta dayalı yöntemler

\begin{tabular}{|c|c|c|c|c|c|}
\hline Yazarlar & Araştırma Türü/Örneklemi & Ölçüm Aracı & Uygulama & Elde edilen sonuç & $\begin{array}{l}\text { Kanit } \\
\text { düzeyi }\end{array}$ \\
\hline & & & Defa 20 saniye uygulanmıştrr. & & \\
\hline $\begin{array}{l}\text { Eduardo ve } \\
\text { ark. } 2015\end{array}$ & $\begin{array}{l}\text {-Tek merkezli vaka-kontrol çalış̧ası } \\
\text {-Kemik iliği nakli olan hastalar ( } \mathrm{n}=51,1 \\
\text { ay-18 yaş) }\end{array}$ & -DSÖ OM skalası & 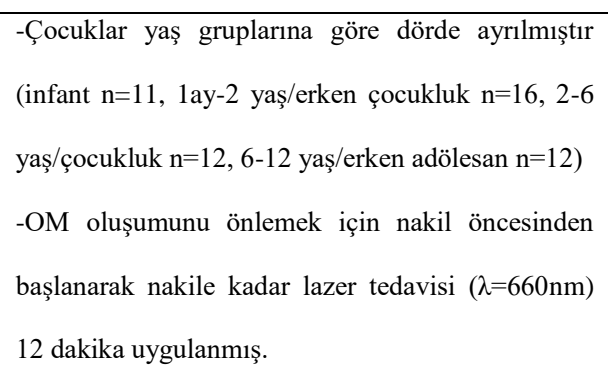 & $\begin{array}{l}\text {-Tüm yaş gruplarnnda Evre I-II OM görüldüğü ve yaşlar } \\
\text { arasısnda fark olmadığı belirtilmiş̧tir. } \\
\text {-Düşük yoğunluklu lazer tedavisinin kemik iliği nakli olan } \\
\text { hastalarda Evre III-IV OM gelişimini engellediği sonucuna } \\
\text { varılmıștır. }\end{array}$ & IV \\
\hline $\begin{array}{l}\text { Amadori ve } \\
\text { ark. } 2016\end{array}$ & $\begin{array}{l}\text {-Tek merkezli randomize kontrollü çift } \\
\text { kör çalş̧ma } \\
\text {-Kemoterapi tedavisi gören, OM Evresi } \\
\text { II ve üzeri olan hastalar (n=123, 3-18 } \\
\text { yą) }\end{array}$ & $\begin{array}{l}\text {-DSÖ OM skalası, } \\
\text {-VAS }\end{array}$ & 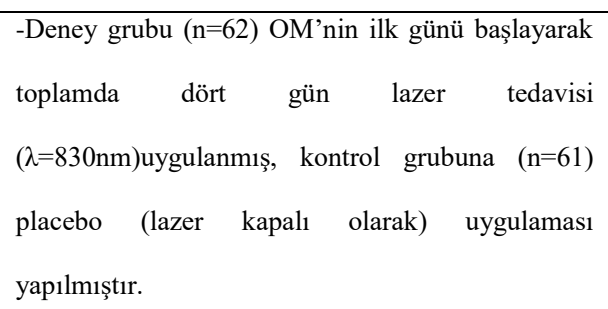 & $\begin{array}{l}\text {-Lazer tedavisi uygulanan grupta OM ağrisında azalma } \\
\text { saptanmıștr }(\mathrm{p}<0,05) \text {. } \\
\text {-OM evrelerine lazer tedavisinin etki etmediği belirtilmiştir } \\
(\mathrm{p}=0,07) \text {. }\end{array}$ & II \\
\hline $\begin{array}{l}\text { Silva ve ark. } \\
2018\end{array}$ & $\begin{array}{l}\text {-Tek merkezli randomize kontrollü üç } \\
\text { kör çalışma } \\
\text {-Kemoterapi alan, Evre I'den yüksek } \\
\text { OM'i olan hastalar (n=29, } 10 \text { ay-18 yaş) }\end{array}$ & $\begin{array}{l}\text {-DSÖ OM skalası, } \\
\text {-ChIMES }\end{array}$ & $\begin{array}{l}\text {-Fotodinamik tedavi grubunda (n=14), OM lezyonu } \\
\% 0,01 \text { metilen mavisi ile boyandiktan sonra kırmızı } \\
\text { lazer uygulanmıșţr }(\lambda=660 \mathrm{~nm}) . \\
\text {-Kontrol grubunda (n=15) OM lezyonu bir dakika } \\
\text { DYLT ( } \lambda=660 \mathrm{~nm} \text { ) uygulanmışțr. }\end{array}$ & $\begin{array}{l}\text {-Fotodinamik tedavi uygulanan grupta hastaların } 4 \text {. gün ağrı } \\
\text { ortalamaları }(1,86 \pm 3,88) \text { DYLT uygulanan gruba }(1,93 \pm 2,31) \\
\text { göre daha düşük olduğu, ancak farkın anlamlı bulunmadı̆ı̆ } \\
\text { belirtilmişțir (p=0,258). }\end{array}$ & II \\
\hline
\end{tabular}




\section{Yurdakul 0.2 ve ark. Kanserli çocuklarda Oral Mukozit}

JCP2018;16(3):51-78

Tablo 2. Devam. Kanserli çocuklarda oral mukozite yönelik kullanılan kantta dayalı yöntemler

\begin{tabular}{|c|c|c|c|c|c|}
\hline Yazarlar & Araştırma Türü/ Örneklemi & Ölçüm Aracı & Uygulama & Elde edilen sonuç & $\begin{array}{l}\text { Kanit } \\
\text { düzeyi }\end{array}$ \\
\hline $\begin{array}{l}\text { Cheng ve } \\
\text { Chang } 2003\end{array}$ & $\begin{array}{l}\text {-Tek merkezli prospektif randomize iki } \\
\text { dönem çapraz geçiş çalşşması } \\
\text {-Yüksek doz kemoterapi alan hastalar } \\
\text { (n=34, 6-17 yaş) }\end{array}$ & $\begin{array}{l}\text {-DSÖ OM skalası } \\
\text {-VAS }\end{array}$ & $\begin{array}{l}\text {-Kemoterapinin ilk günü başlayarak } 21 \text { gün } \\
\text { boyunca klinik ağı bakım protokolüne ek olarak } \\
\text { bir grup klorheksidin (n=17) bir grup benzidamin } \\
(\mathrm{n}=17) \text { gargara kullanmış, bir sonraki kürde } \\
\text { solüsyonlar çaprazlanarak klorheksidin grubu } \\
\text { benzidamin, benzidamin grubu klorheksidin } \\
\text { kullanmışltrr. }\end{array}$ & 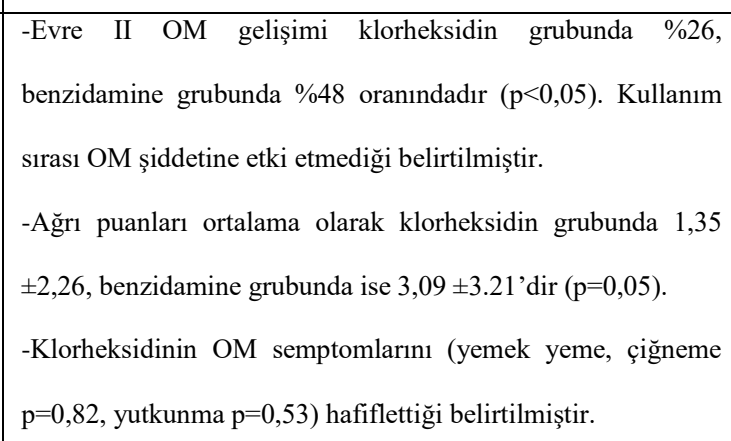 & II \\
\hline $\begin{array}{l}\text { Costa ve ark. } \\
2003\end{array}$ & $\begin{array}{l}\text {-Tek merkezli randomizasyonun } \\
\text { olmadı̆ı̆ı deney kontrollü çalı̧̧ma } \\
\text {-Yüksek doz kemoterapi alan akut } \\
\text { lenfoblastik lösemi hastaları (n=14, 2-10 } \\
\text { yaş) }\end{array}$ & -Belirtilmemiş & $\begin{array}{l}\text {-Çalışma grubuna }(\mathrm{n}=7) \% 0,12 \text { klorheksidinli } \\
\text { gargarayla, kontrol grubuna }(\mathrm{n}=7) \text { plasebo gargara } \\
\text { ile kemoterapiden en az bir gün önce başlanarak on } \\
\text { gün boyunca ortalama sekiz hafta } 2 \times 1 \text { gargara } \\
\text { yapttrlılııststr. }\end{array}$ & $\begin{array}{l}\text {-Klorheksidin gargara kullanların \%14,3'üunde, kontrol } \\
\text { grubunun \%71,4'ünde OM ve ülserasyon görülmüş̧ür } \\
\text { (p }<0,05) \text {. } \\
\text {-Klorheksidinin OM'nin insidansinda azalma sağladığı } \\
\text { belirtilmiştir. }\end{array}$ & III \\
\hline $\begin{array}{l}\text { Cheng ve } \\
\text { ark. } 2004\end{array}$ & $\begin{array}{l}\text {-Tek merkezli prospektif randomize iki } \\
\text { dönem çapraz geçiş çalş̧ması } \\
\text {-Ardı̧ıık iki kür yüksek doz kemoterapi } \\
\text { alan hastatar (n=34, 6-17 yaş) }\end{array}$ & $-\mathrm{OAG}$ & 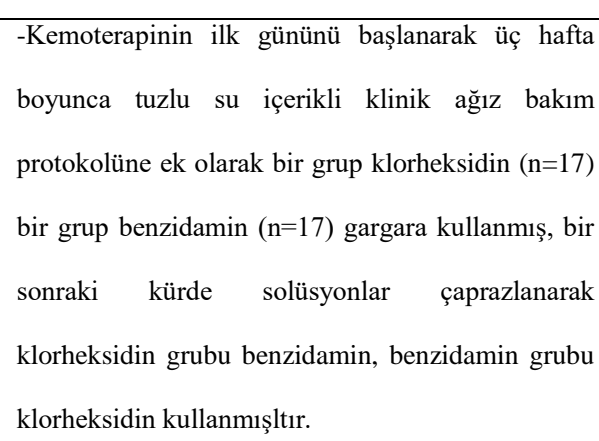 & $\begin{array}{l}\text {-OAG skoru klorheksidin grubunda }(0-17,5) \text { benzydamine } \\
\text { grubuna (0-26) daha düs̆üktür. } \\
\text {-Koruyucu olarak klorheksidinli gargara ve ağız bakım } \\
\text { protokolü kullanımıın ülseratif lezyonlarda ve mukozit } \\
\text { șiddetinde azalma sağlayabileceği belirtilmiştir ( }<00.05) \text {. }\end{array}$ & II \\
\hline
\end{tabular}


Yurdakul 0.2 ve ark. Kanserli çocuklarda Oral Mukozit

JCP2018;16(3):51-78

Tablo 2. Devam. Kanserli çocuklarda oral mukozite yönelik kullanılan kantta dayalı yöntemler

\begin{tabular}{|c|c|c|c|c|c|}
\hline Yazarlar & Araştırma Türü/ Örneklemi & Ölçüm Arac1 & Uygulama & Elde edilen sonuç & $\begin{array}{l}\text { Kanit } \\
\text { düzeyi }\end{array}$ \\
\hline $\begin{array}{l}\text { Pinto ve ark. } \\
2006\end{array}$ & $\begin{array}{l}\text {-Tek merkezli randomizasyonun } \\
\text { olmadı̆ı̆ deney kontrollü çalışma } \\
\text {-Akut lenfoblastik lenfoma tanılı } \\
\text { hastalar (n=33, 2-15 yaş) }\end{array}$ & $\begin{array}{l}- \text {-OM } \\
\text { değerlendirmeleri } \\
\text { Epstein ve ark. } \\
\text { (2000) kriterlerine } \\
\text { göre yapılmıșţr. }\end{array}$ & $\begin{array}{l}- \text { Klorheksidin } \quad \text { grubuna } \quad(\mathrm{n}=23), \quad 2 \times 1 \quad \% 0,12 \\
\text { klorheksidinli gargara ya da } \% 0.12 \text { klorheksidinle } \\
\text { islatllmıs pamukla bakım verilmiștir. } \\
\text {-Kontrol gurubuna }(\mathrm{n}=10) \text { tedavi uygulanmamıștr. }\end{array}$ & $\begin{array}{l}\text {-Klorheksidinli gargara uygulanan çocuklarda (\%26) kontrol } \\
\text { grubuna göre }(\% 80) \quad \text { OM insidansında azalma sağladığı } \\
\text { belirtilmiştir }(\mathrm{p}=0,007) .\end{array}$ & III \\
\hline $\begin{array}{l}\text { Lauritano ve } \\
\text { ark. } 2014\end{array}$ & $\begin{array}{l}\text {-Vaka-kontrol çalş̧̧ması } \\
\text {-Allojenik kök hücre nakli olan hastalar } \\
(\mathrm{n}=40,7-16 \text { yaş) }\end{array}$ & -DSÖ OM skalası & $\begin{array}{l}\text {-Callı̧ma grubuna }(\mathrm{n}=20) \text { palifermin } 60 \mu \mathrm{g} / \mathrm{kg} / \text { gün } \\
\text { intravenöz yolla myeloblastif tedaviden ụ̈ gün } \\
\text { önce ve tedaviden sonraki üç gün ardışılk olarak } \\
\text { toplamda altı gün boyunca uygulanmıştr. } \\
\text {-Kontrol gurubuna (n=20) Benzidamin hidroklorid } \\
\text { ile gargara uygulanmıșțr. }\end{array}$ & 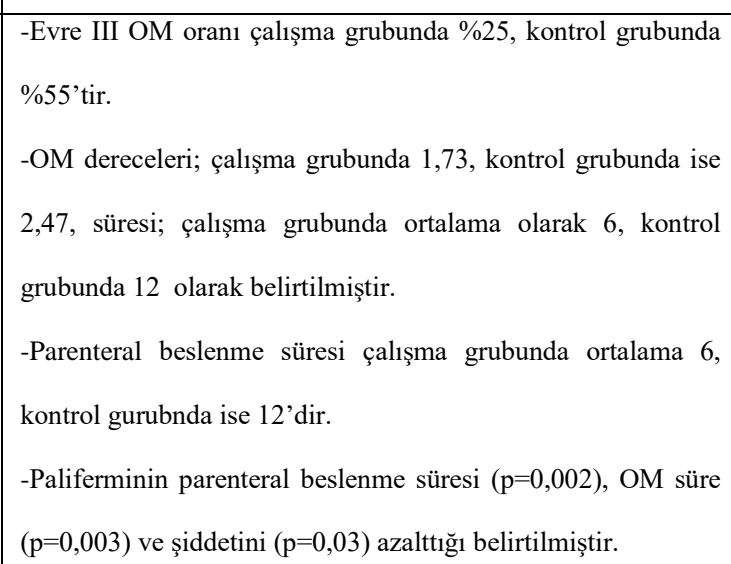 & IV \\
\hline $\begin{array}{l}\text { Gholizadeh } \\
\text { ve ark. } 2016\end{array}$ & $\begin{array}{l}\text {-Tek merkezli randomize kontrollü } \\
\text { çalşsma } \\
\text {-Akut lenfoblastik lösemili hastalar } \\
\text { (n=90, 5-18 yaş) }\end{array}$ & -DSÖ OM skalası & 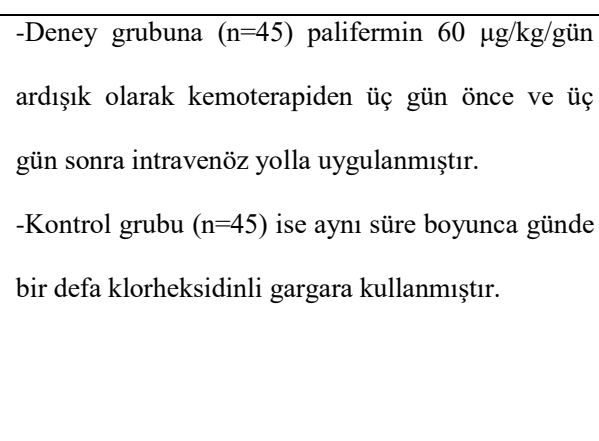 & 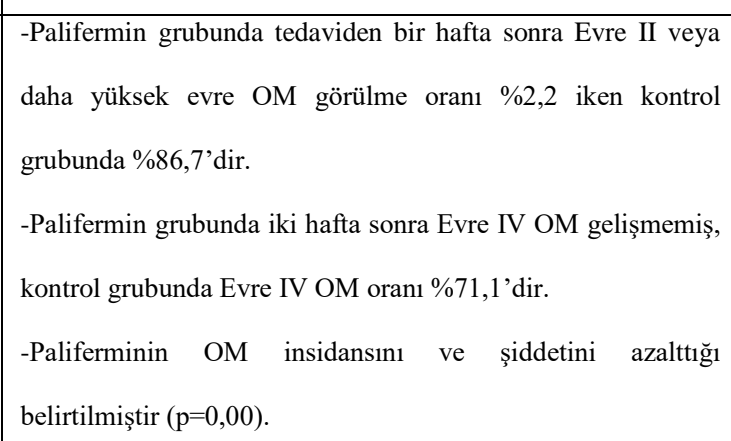 & II \\
\hline
\end{tabular}


Yurdakul 0.2 ve ark. Kanserli çocuklarda Oral Mukozit

JCP2018;16(3):51-78

Tablo 2. Devam. Kanserll çocuklarda oral mukozite yönelik kullanıllan kantta dayalı yöntemler

\begin{tabular}{|c|c|c|c|c|c|}
\hline Yazarlar & Araş̧trma Türü/ Örneklemi & Ölçüm Aracı & Uygulama & Elde edilen sonuç & $\begin{array}{l}\text { Kanit } \\
\text { düzeyi }\end{array}$ \\
\hline $\begin{array}{l}\text { Morris } \\
\text { ark. } 2016\end{array}$ & $\begin{array}{l}\text {-Çok merkezli kohort çallşması } \\
\text {-Myeloblatif kök hücre nakli olan } \\
\text { hastalar (n=27, 1-16 yas) }\end{array}$ & -DSÖ OM skalası & 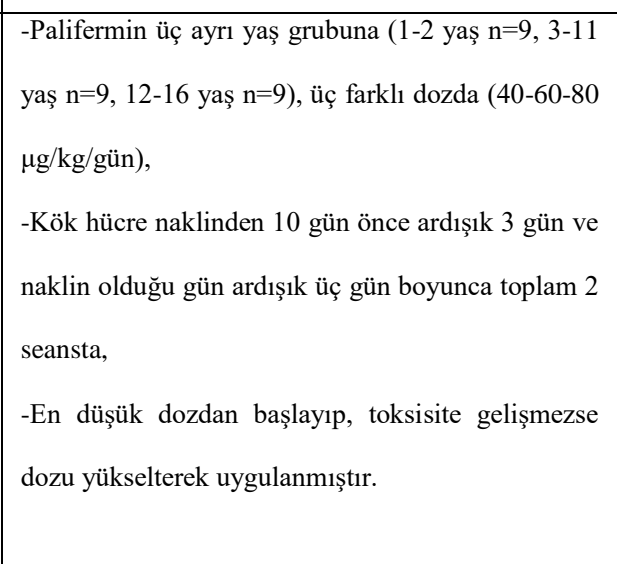 & 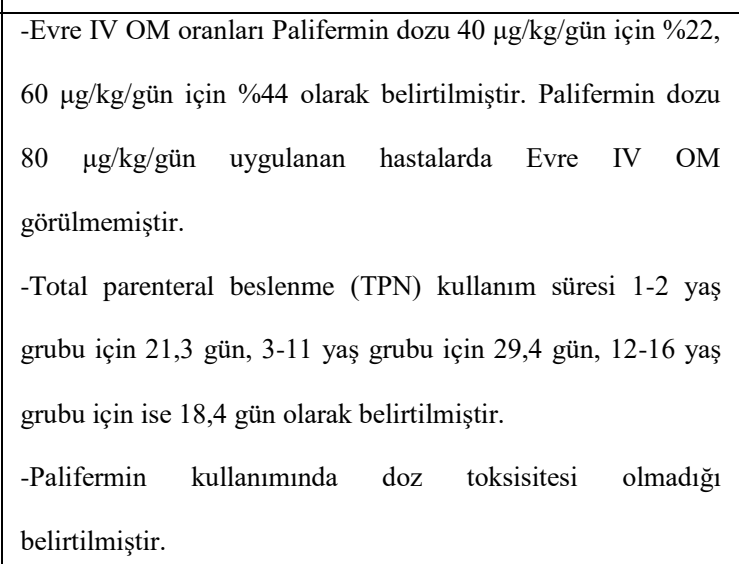 & IV \\
\hline $\begin{array}{l}\text { Vitale ve ark. } \\
2017\end{array}$ & $\begin{array}{l}- \text {-Tek merkezli randominizasyonun } \\
\text { olmadı̆ı̆ı retrospektif deney kontrollü } \\
\text { çalş̧ma } \\
\text {-Otolog hematopoetik kök hücre nakli } \\
\text { olan hastalar (n=58; palifermin gurubu } \\
7,96 \pm 6,19 \text { yaş, kontrol grubu } 6,85 \pm 5,49 \\
\text { yaş) }\end{array}$ & -DSÖ OM skalası & $\begin{array}{l}\text {-Deney grubuna ( } \mathrm{n}=25) \text { kemoterapinin } 0,1 \text { ve } 2 \text {. } \\
\text { günleri ve kemoterapi bitiminden sonraki ụ̈ gün } \\
\text { boyunca klinik protokolïyle birlikte } 60 \mu g \mathrm{~kg} / \text { gün } \\
\text { Palifermin intravenöz olarak uygulanmış, kontrol } \\
\text { grubuna ( } \mathrm{n}=33 \text { ) ise sadece klinik ağız bakım } \\
\text { protokolü uygulanmıştr. }\end{array}$ & 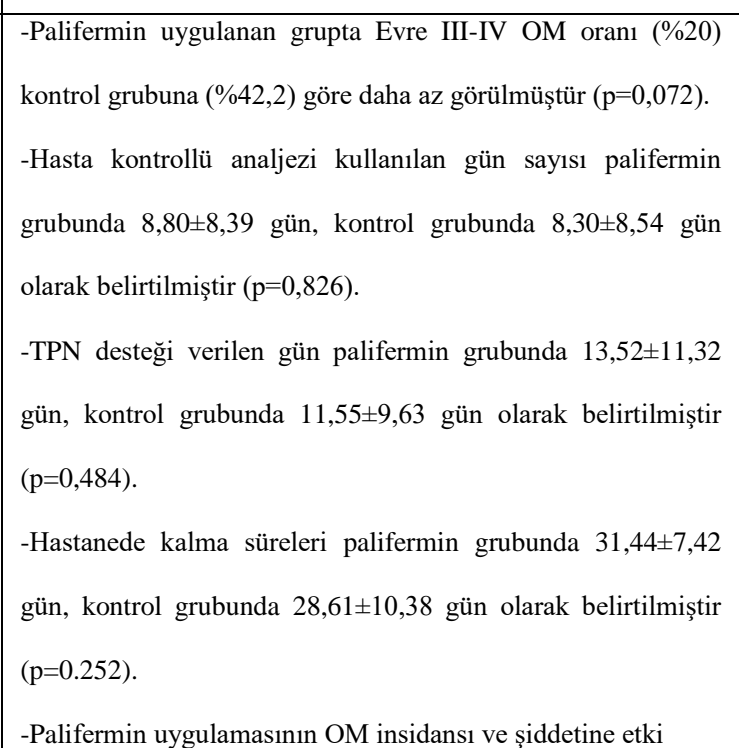 & III \\
\hline
\end{tabular}


Yurdakul $0 . z$ ve ark. Kanserli çocuklarda Oral Mukozit

JCP2018;16(3):51-78

Tablo 2. Devam. Kanserli çocuklarda oral mukozite yönelik kullanılan kantta dayalı yöntemler

\begin{tabular}{|c|c|c|c|c|c|}
\hline Yazarlar & Araştırma Türü// Örneklemi & Ölçüm Aracı & Uygulama & Elde edilen sonuç & $\begin{array}{l}\text { Kanıt } \\
\text { düzeyi }\end{array}$ \\
\hline & & & & $\begin{array}{l}\text { etmediği, hastanede yațş süresini uzatarak maliyeti artturdığ } \\
\text { belirtilmiş̧tir. }\end{array}$ & \\
\hline $\begin{array}{l}\text { Abdulrhman } \\
\text { ve ark. } 2012\end{array}$ & $\begin{array}{l}\text {-Tek merkezli randomize kontrollü } \\
\text { çalışmma } \\
\text {-Akut lenfoblastik lösemi tanıll, Evre II } \\
\text { ya da III OM'si olan hastalar (n=90, 2- } \\
18 \text { yaş) }\end{array}$ & -NCI-CTC & 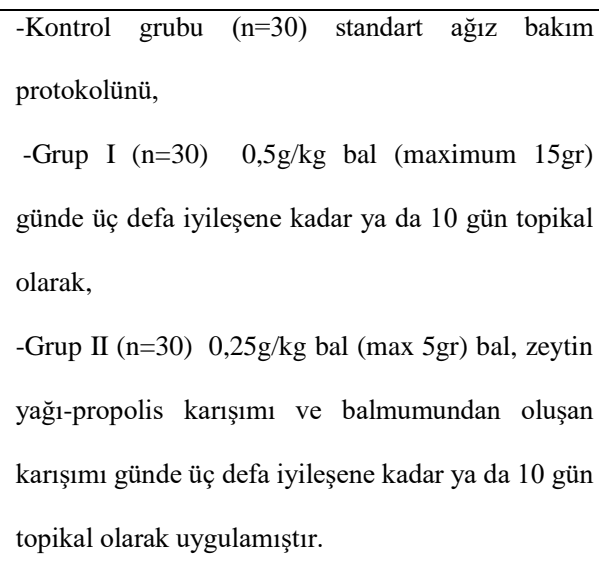 & $\begin{array}{l}\text {-Grup I'de diğer gruplara göre Evre II OM'de azalma } \\
\text { ( }<<0,05) \text {, } \\
\text {-Bal gruplarnda kontrol grubuna göre iyileşmede hızlanma } \\
\text { olduğu belirtilmiştir }(\mathrm{p}<0,05) \text {. }\end{array}$ & II \\
\hline $\begin{array}{l}\text { Bulut ve } \\
\text { Tüfekçi } 2016\end{array}$ & $\begin{array}{l}\text {-Tek merkezli randomize olmayan } \\
\text { deney kontrol çalışma } \\
\text {-Kemoterapi alan hastalar (n=76, 6-18 } \\
\text { yaş) }\end{array}$ & -DSÖ OM skalası & $\begin{array}{l}\text {-Bal grubundaki (n=37) } 14 \text { çocuğa klinik ağız } \\
\text { bakımı ve bal (kemoterapi başlangıınndan } 7-14 \text { gün } \\
\text { arasında), OM geliştikten sonra gruba dahil edilen } \\
23 \text { çocuğa ise bal uygulanmıststr. Balın (1 } 1 \text { grkg) } \\
\text { günde } 4 x 1 \text { en az bir dakika ağız içinde tutulması ve } \\
\text { yavaş̧a yutulması istenmiş. } \\
\text {-Kontrol grubuna (n=39) klinik ağı bakım } \\
\text { protokolü uygulanmıştır. }\end{array}$ & 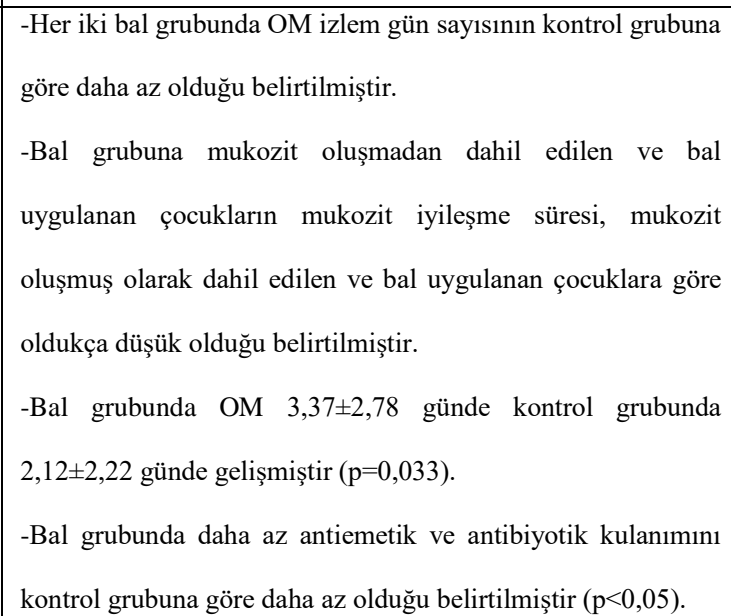 & III \\
\hline
\end{tabular}


Yurdakul 0.2 ve ark. Kanserli çocuklarda Oral Mukozit

JCP2018;16(3):51-78

Tablo 2. Devam. Kanserli çocuklarda oral mukozite yönelik kullanılan kantta dayalı yöntemler

\begin{tabular}{|c|c|c|c|c|c|}
\hline Yazarlar & Araştırma Türü/ Örneklemi & Ölçüm Aracı & Uygulama & Elde edilen sonuç & $\begin{array}{l}\text { Kanıt } \\
\text { düzeyi }\end{array}$ \\
\hline & & & & $\begin{array}{l}\text {-Ciddi OM gelişimi bal grubunda kontrol grubuna göre daha } \\
\text { az olduğu sonucuna ulaşılmısttr }(p<0.05) \text {. }\end{array}$ & \\
\hline $\begin{array}{l}\text { AL Jonouski } \\
\text { ve ark. } 2017\end{array}$ & $\begin{array}{l}\text {-Tek merkezli randomize kontrollü } \\
\text { çalşsma } \\
\text {-Kemoterapi ve radyoterapi alan hastalar } \\
(\mathrm{n}=40 \text {, ortalama } 8 \text { yaş) }\end{array}$ & -DSÖ OM skalası & 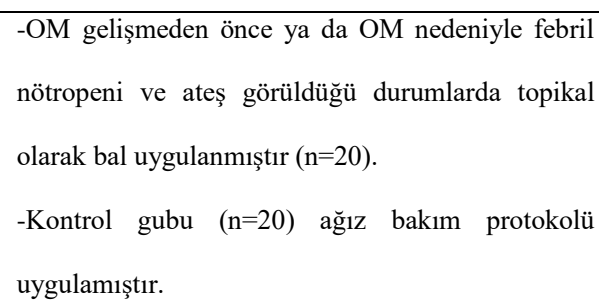 & $\begin{array}{l}\text {-Balın topikal olarak uygulanmasını candida ve aerobik } \\
\text { patojen bakteri kolonizasyonu ve ağrnyı azalttı̆ı̆ }(\mathrm{p}<0,05) \text {, } \\
\text {-Enfeksiyonu önlediği ( } \mathrm{p}=0,003) \text {, } \\
\text {-Hastanede kalma süresinde azalma(bal grubu } 7 \pm 3 \text { gün, } \\
\text { kontrol grubu } 13 \pm 5 \text { gün) sağladı̆ı̆ belirtilmiștir. }\end{array}$ & II \\
\hline $\begin{array}{l}\text { El- } \\
\text { Housseiny ve } \\
\text { ark. } 2007\end{array}$ & $\begin{array}{l}\text {-Çok merkezli randomize kontrollü } \\
\text { çalşsma } \\
\text {-Kemoterapi alan hastalar (n=80, } 12 \text { yas } \\
\text { altı) }\end{array}$ & - DSÖ OM skalası & 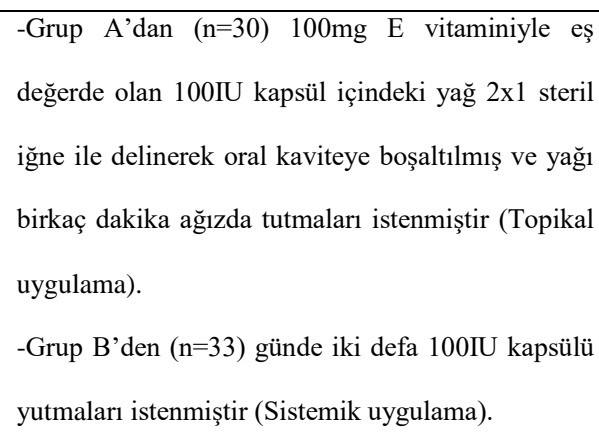 & 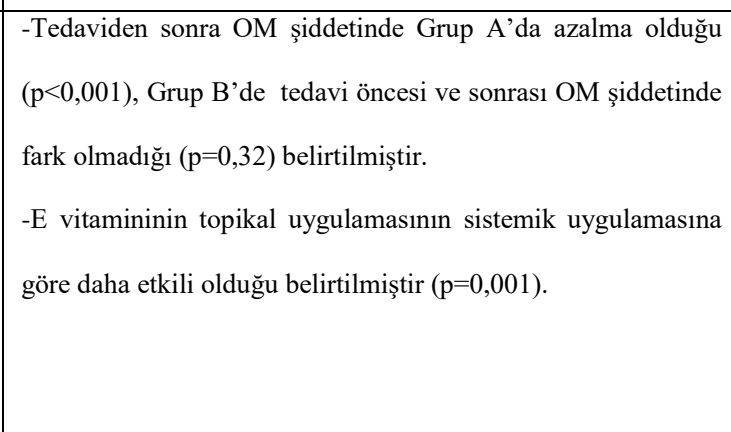 & II \\
\hline $\begin{array}{l}\text { Sung ve ark. } \\
2007\end{array}$ & $\begin{array}{l}\text {-Tek merkezli randomize kontrollü çift } \\
\text { kör çalışma } \\
\text {-Doxorubicin alan hastalar (n=55, } 6 \text { yas } \\
\text { üstui) }\end{array}$ & $\begin{array}{l}\text {-Sonis tarafindan } \\
\text { geliştirilen skala } \\
\text {-VAS } \\
\text {-DSÖ OM skalası }\end{array}$ & 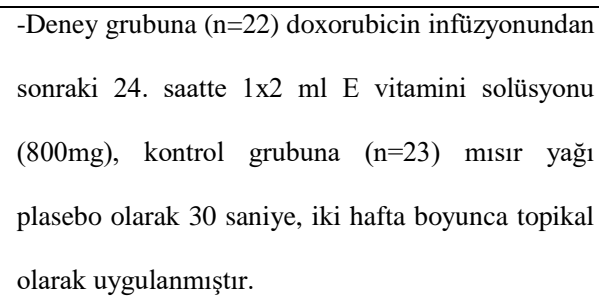 & $\begin{array}{l}- \text {-Topikal E vitamini uygulaması OM üzerinde etkili } \\
\text { bulunmamıştr }(\mathrm{p}<0,05) \text {. }\end{array}$ & II \\
\hline
\end{tabular}


Yurdakul 0.2 ve ark. Kanserli çocuklarda Oral Mukozit

JCP2018;16(3):51-78

Tablo 2. Devam. Kanserli çocuklarda oral mukozite yönelik kullanılan kantta dayalı yöntemler

\begin{tabular}{|c|c|c|c|c|c|}
\hline Yazarlar & Araştrrma Türü/ Örneklemi & Ölçüm Aracı & Uygulama & Elde edilen sonuç & $\begin{array}{l}\text { Kanit } \\
\text { düzeyi }\end{array}$ \\
\hline $\begin{array}{l}\text { Khurana ve } \\
\text { ark. } 2013\end{array}$ & $\begin{array}{l}\text {-Tek merkezli tek kör randomize } \\
\text { kontrollü çalşmma } \\
\text {-Kemoterapi alan hastalar (n=72, 6-15 } \\
\text { yaş) }\end{array}$ & \begin{tabular}{|l|}
-OMAS \\
-ChIMES
\end{tabular} & 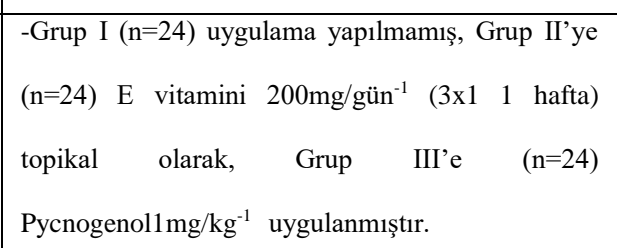 & $\begin{array}{l}\text {-E vitamini ve Pycnogenol OM'nin tedavi edilmesinde etkin } \\
\text { olduğu, ancak Pycnogenol' in Evre IV OM'yi tedavi etmede } \\
\text { etkin olmadı̆ ı̌ belirtilmiş̧tr. }\end{array}$ & II \\
\hline $\begin{array}{l}\text { Ward ve ark. } \\
2009\end{array}$ & $\begin{array}{l}\text {-Tek merkezli randomize kontrollü } \\
\text { çalşsma } \\
\text {-Kemoterapi alan hastalar ( } \mathrm{n}=50,1-22 \\
\text { yaş) }\end{array}$ & -NCI-CTC & $\begin{array}{l}\text {-Aynı hasta grubunda }(\mathrm{n}=50) \text { aynı kemoterapi kürü } \\
\text { bir kez glutamin desteğiyle birlikte bir kez de } \\
\text { glutamin desteği olmadan uygulanmıştr. } \\
\text {-Glutamin }\left(0,65 \mathrm{~g} / \mathrm{kg}^{-1}\right) \text { kemoterapinin ilk günü } \\
\text { başlayarak yedi gün boyunca } 10 \mathrm{~g} / 100 \mathrm{ml} \text { su ile oral } \\
\text { ya da beslenme tüpünden uygulanmışstr. }\end{array}$ & $\begin{array}{l}\text {-Glutamin desteği ile verilen kürlerde daha az enteral } \\
\text { nütrisyona ihtiyaç duyulmuş ve nütrisyon destek süresi } \\
\text { (Glutamin ile: } 12,0 \pm 10,3 \text {, Glutaminsiz; } 8,8 \pm 9,7 \text { ) daha kısa } \\
\text { sürmüștür (p=0,026). } \\
\text {-Ancak yüksek doz enteral glutamin uygulamasııı OM } \\
\text { insdansnda ve şiddetinde azalma sağlamadı̆ı̆ belirtilmiştir } \\
\text { (p<0,05). }\end{array}$ & II \\
\hline $\begin{array}{l}\text { Chang ve } \\
\text { ark. } 2017\end{array}$ & $\begin{array}{l}\text {-Tek merkezli randominizasyonun } \\
\text { olmadı̆ı̆ı deney kontrol çalş̧ma } \\
\text {-Yüksek doz metotreksat alan akut } \\
\text { lenfoblastik tanlı hastalar (n=96, } 18 \text { yaş } \\
\text { altı) }\end{array}$ & -DSÖ OM skalası & 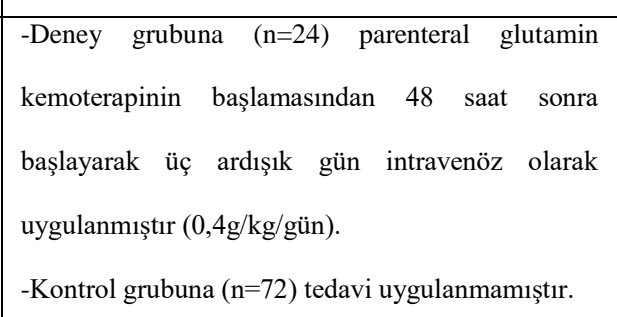 & $\begin{array}{l}\text {-Glutamin grubunda }(\% 3,8) \text { kontrol grubuna }(\% 17,6) \text { göre OM } \\
\text { insidansinda azalma görülmüş̧tür }(\mathrm{p}=0,004) \text {. } \\
\text {-Glutamin grubunda şiddetli OM gelişmediği belirtilmiştir. }\end{array}$ & III \\
\hline $\begin{array}{l}\text { Sato ve ark. } \\
2006\end{array}$ & $\begin{array}{l}\text {-Tek merkezli randominizasyonun } \\
\text { olmadı̆̆ı deney kontrollü çalışma }\end{array}$ & -DSÖ OM skalası & $\begin{array}{l}\text {-Propanthelin }(15 \mathrm{mg} / \mathrm{kg} / \text { gün) kriyoterapiden önce } \\
\text { bir gün uygulanmıs ve nakilden bir gün önce }\end{array}$ & $\begin{array}{l}\text {-Propanthelin ve kriyoterapinin kombine olarak kullanııldığ } 1 \\
\text { grupta Evre II-IV ve III-IV OM oran } \% 8.3^{3} \text { tür. }\end{array}$ & III \\
\hline
\end{tabular}


Yurdakul 0.2 ve ark. Kanserli çocuklarda Oral Mukozit

JCP2018;16(3):51-78

Tablo 2. Devam. Kanserli çocuklarda oral mukozite yönelik kullanılan kantta dayalı yöntemler

\begin{tabular}{|c|c|c|c|c|c|}
\hline Yazarlar & Araş̧trma Türü/ Örneklemi & Ölçüm Aracı & Uygulama & Elde edilen sonuç & $\begin{array}{l}\text { Kant } \\
\text { düzzyi }\end{array}$ \\
\hline & $\begin{array}{l}\text { - Myeloablatif kemo-radyoterapi alan ve } \\
\text { otolog kemik iliği nakli olan hasta } \\
\text { (n=24, 2-16 yaş) }\end{array}$ & & 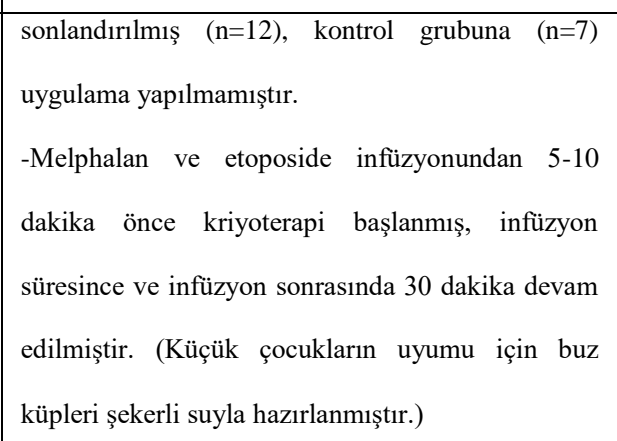 & $\begin{array}{l}\text { - Propanthelin (n=4) ya da kriyoterapinin (n=1) tek olarak } \\
\text { kullanııldığı beş kişilik grupta OM oranı arasında anlamlı fark } \\
\text { bulunmamıștr. } \\
\text {-Kontrol grubunda Evre II-IV OM oranı \% } 71,4^{\prime} \text { tür. } \\
\text {-Propanthelinle kombine kullanılan kriyoterapide, şiddetli OM } \\
\text { (Evre III-IV) riskinde azalma gözlenmiş̧tir ( }(\mathrm{p}=0,0069) \text {. }\end{array}$ & \\
\hline $\begin{array}{l}\text { Gori ve ark. } \\
2007\end{array}$ & $\begin{array}{l}\text {-Çok merkezli prospektif randomize } \\
\text { çalış̧ma } \\
\text {-Myeloablatifi allojenik kök hücre nakli } \\
\text { olan hastalar (n=122, 8-66 yaş) }\end{array}$ & -DSÖ OM skalası & $\begin{array}{l}\text {-Deney grubuna (n=62) metotreksat infüzyonu } \\
\text { başlayinca en az bir saat kriyoterapi uygulanmış, } \\
\text { kontrol grubuna }(\mathrm{n}=60) \text { uygulama yapılmamış̧tr. }\end{array}$ & $\begin{array}{l}\text {-Evre III-IV OM kriyoterapi uygulanan hastlarda } \% 46,7 \text {, } \\
\text { kontrol grubunda } \% 53,3 \text { 'tür ve aralarnnda anlamlı bir fark } \\
\text { bulunmamıștrt ( } \mathrm{p}=0.46 \text { ). } \\
\text {-Profilaktik kriyoterapinin OM şiddetini ( } \mathrm{p}=0,92 \text { ) ve süresini } \\
\text { etkilemediği (kriyoterapi grubu } 1,98 \pm 71,12 \text {, kontrol grubu } \\
2,13 \pm 1,24, \mathrm{p}=0,56 \text { ) gösterilmiş̧ir. }\end{array}$ & II \\
\hline $\begin{array}{l}\text { Gandemar ve } \\
\text { ark. } 2007\end{array}$ & $\begin{array}{l}\text {-Çok merkezli randomize kontrollü } \\
\text { çalışsma } \\
\text {-Kemoterapi alan hastalar (n=145, 5-18 } \\
\text { yaş) }\end{array}$ & \begin{tabular}{|l} 
- DSÖ OM skalas1 \\
-VAS
\end{tabular} & 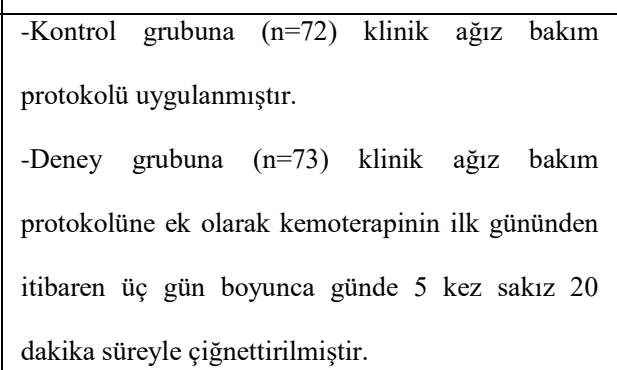 & $\begin{array}{l}\text {-Evre I-IV OM deney grubunda \% } 49 \text {, kontrol grubunda } \% 72 \\
\text { oranında gözlemlenmiş ( } \mathrm{p}=0,03) \text {, } \\
\text {-Ciddi OM median zamanı gruplar arasında farklılık } \\
\text { göstermemiş̧tir ( } \mathrm{p}=0,54) \text {, } \\
\text {-Sakız ciğnemenin Evre I-II OM insidansııı azaltabileceği } \\
\text { belirtilmișţir. }\end{array}$ & II \\
\hline
\end{tabular}


Yurdakul 0.2 ve ark. Kanserli çocuklarda Oral Mukozit

JCP2018;16(3):51-78

Tablo 2. Devam. Kanserli çocuklarda oral mukozite yönelik kullanılan kantta dayalı yöntemler

\begin{tabular}{|c|c|c|c|c|c|}
\hline Yazarlar & Araş̧trma Türü/ Örneklemi & Ölçüm Aracı & Uygulama & Elde edilen sonuç & $\begin{array}{l}\text { Kanit } \\
\text { düzeyi }\end{array}$ \\
\hline $\begin{array}{l}\text { Eghbali ve } \\
\text { ark. } 2015\end{array}$ & $\begin{array}{l}\text {-Tek merkezli randomize kontrollü } \\
\text { calışma } \\
\text {-Kemoterapi alan hastalar (n=130, 5-15 } \\
\text { yaş) }\end{array}$ & \begin{tabular}{|l|}
-DSÖ OM skalası \\
\end{tabular} & $\begin{array}{l}\text {-Deney grubundaki hastalara (n=62) standat ağız } \\
\text { bakım protokolüne ek olarak } 15 \text { gün süreyle günde } \\
\text { altı defa } 30 \text { dakika boyunca sekersiz sakız } \\
\text { ciğnettirilmiş. } \\
\text {-Kontrol grubu (n=62) sadece standart ağız bakım } \\
\text { protokolünüu uygulamıststr. }\end{array}$ & 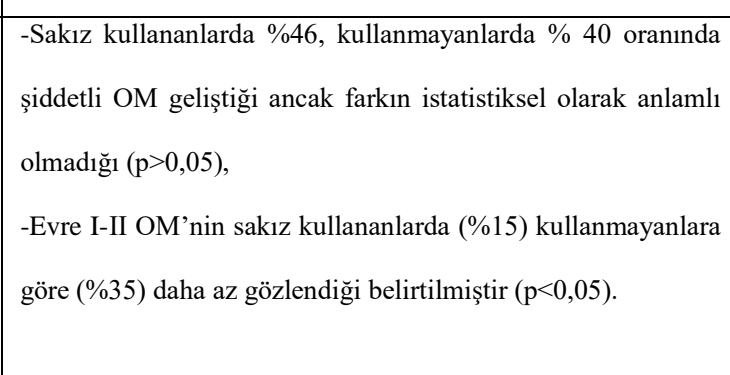 & II \\
\hline $\begin{array}{l}\text { Oberbaum ve } \\
\text { ark. } 2001\end{array}$ & $\begin{array}{l}\text {-Tek merkezli randomize kontrollü cift } \\
\text { kör calış̧ma } \\
\text {-Kök hücre nakli olan hastalar (n=30,3- } \\
25 \text { yaş) }\end{array}$ & \begin{tabular}{|l} 
- DSÖ OM skalası \\
-Walsh skala
\end{tabular} & $\begin{array}{l}\text {-Tüm hastalar iki gün } 2 \times 1 \text { klinik ağız bakım } \\
\text { protokolünü uyguladıktan sonra nakilin 2. günü } \\
\text { randomize edilerek tedaviye başlanmıştrı. } \\
\text {-Deney grubu (n=15) TRAUMEEL S, kontrol } \\
\text { gurubu (n=15) plasebo etkili solüsyon kullanarak } \\
\text { yutmadan } 30 \text { dakika önce gargara yapmıştr. }\end{array}$ & $\begin{array}{l}\text {-AUC skorlarına göre OM'de artı̧ oranları TRAUMEEL S } \\
\text { grubunda 10,4; plasebo grubunda 24,3'tür. } \\
\text {-Tedavi süresince semptomların (ağız kuruluğu, oral ağrı, } \\
\text { yanma hissi) ilerleme oranları TRAUMEEL S grubunda \%47, } \\
\text { plasebo grubunda } \% 93 \text { olarak belirlenmiștir (p }<0,001 \text { ). }\end{array}$ & II \\
\hline $\begin{array}{ll}\text { Sencer } & \text { ve } \\
\text { ark. } 2012\end{array}$ & $\begin{array}{l}\text {-Çok merkezli randomize kontrollü çift } \\
\text { kör çalış̧ma } \\
\text {-Hematopoetik kök hücre nakli olan } \\
\text { hastalar (n=190,3-25 yaş) }\end{array}$ & \begin{tabular}{|l|}
-DSÖ OM skalas1 \\
-Walsh skala
\end{tabular} & $\begin{array}{l}- \text {-Deney grubunda (n=98) nakilden bir gün önce ve } \\
20 \text { gün sonrasına kadar hastlardan TRAUMEEL S'i } \\
30 \text { saniye gargara yapmaları ve işlemden sonraki } 30 \\
\text { dakika boyunca yemek yememeleri ve su } \\
\text { içmemelerri istenmiştir. } \\
\text {-Kontrol grubuna }(\mathrm{n}=92) \text { uygulama yapılmamıștr. }\end{array}$ & 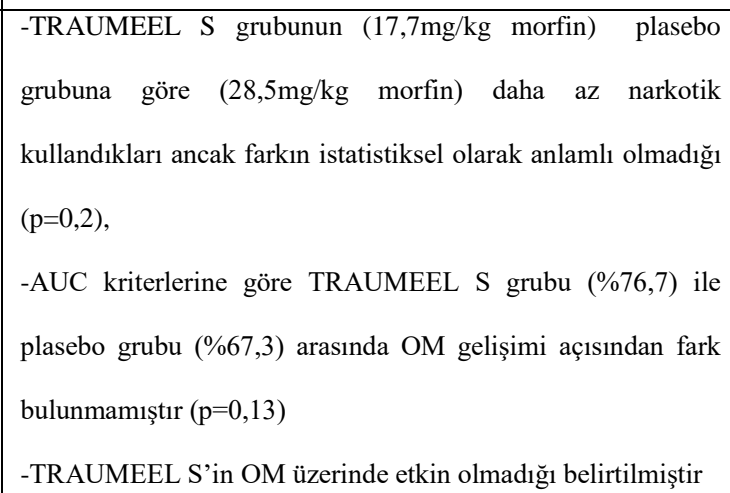 & II \\
\hline
\end{tabular}


Yurdakul $\quad 0 . z$

JCP2018;16(3):51-78

Tablo 2. Devam. Kanserll çocuklarda oral mukozite yönelik kullanılan kantta dayalı yöntemler

\begin{tabular}{|c|c|c|c|c|c|}
\hline Yazarlar & Araştrrma Türü/ Örneklemi & Ölçüm Aracı & Uygulama & Elde edilen sonuç & $\begin{array}{l}\text { Kantt } \\
\text { düzeyi }\end{array}$ \\
\hline $\begin{array}{l}\text { Tomozevic } \\
\text { ve Jazbec } \\
2013\end{array}$ & $\begin{array}{l}\text {-Tek merkezli randomize kontrollü çift } \\
\text { kör çalış̧ma } \\
\text {-Kemoterapi alan hastalar (n=40, 1-19 } \\
\text { yas) }\end{array}$ & $-\mathrm{OAG}$ & $\begin{array}{l}\text {-Tüm gruplara } 2 \times 1 \text { flouridli diş macunuyla } \\
\text { firçalama yaptrrlmı̣s. } \\
\text {-Propolis grubuna }(\mathrm{n}=19) 2 \times 1 \quad 0,38 \text { gr propolis, } \\
\text { kontrol grubuna ( } \mathrm{n}=21) 2 \times 1 \text { placebo uygulaması } \\
\text { yapplmıştr. }\end{array}$ & $\begin{array}{l}\text {-Ciddi OM (Evre III-IV) propolis grubunda \%42, kontrol } \\
\text { grubunda \%48 oranında gelişmiş ve istatistiksel olarak anlamlı } \\
\text { fark bulunamamıştr ( } \mathrm{p}=0,059) \text {. }\end{array}$ & III \\
\hline $\begin{array}{l}\text { Eren ve ark. } \\
2007\end{array}$ & $\begin{array}{l}\text {-Tek merkezli randomize kontrollü } \\
\text { çalı̧ma } \\
\text {-Kemoterapi alan hastalar (n=35, deney } \\
\text { grubu yaş ortalaması } 7,6 \pm 4,5 \text { yll, } \\
\text { kontrol grubu yas ortalaması } 9,7 \pm 4,5 \\
\text { yıl) }\end{array}$ & - DSÖ OM skalası & 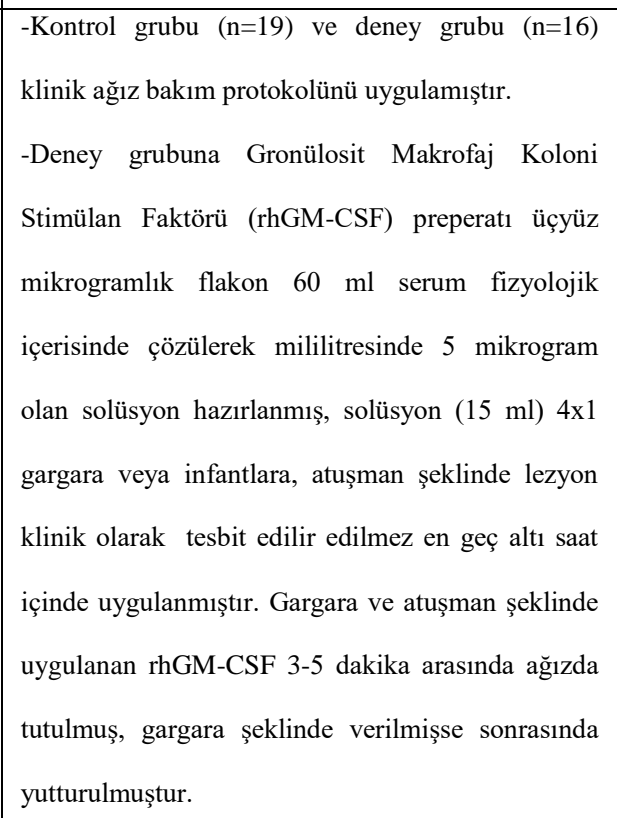 & 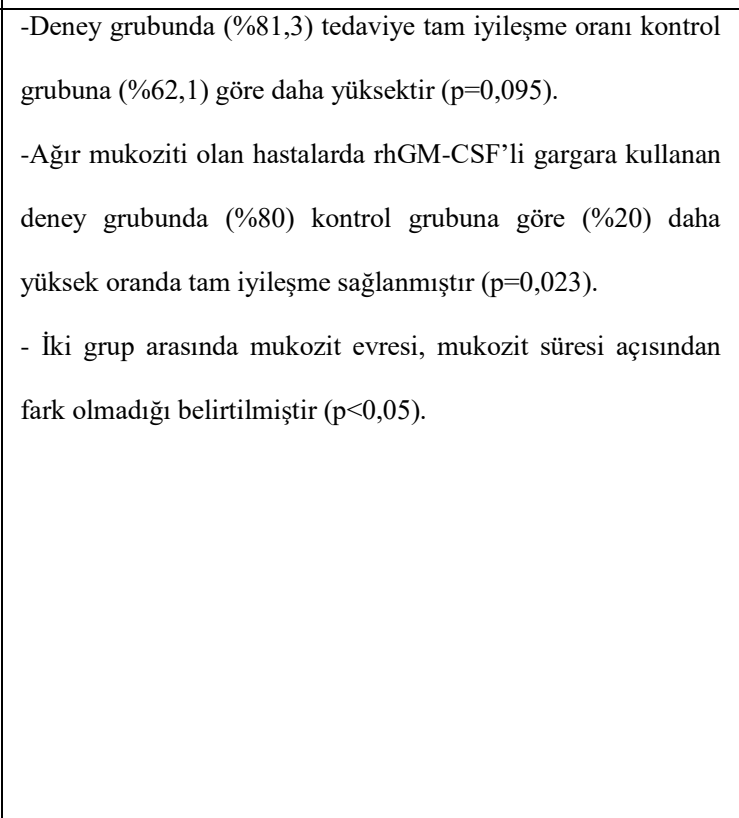 & II \\
\hline $\begin{array}{l}\text { Chermetz ve } \\
\text { ark. } 2014\end{array}$ & $\begin{array}{l}- \text {-Tek merkezli prospektif } \\
\text { gözlemsel/tanımlayııı çalş̧ma } \\
\text {-Kemoterapi ve hematopoetik kök hücre }\end{array}$ & $\begin{array}{l}\text {-DSÖ OM skalası } \\
\text {-VAS }\end{array}$ & $\begin{array}{l}\text {-OM tedavisi için günde iki defa ardlşılk dört gün } \\
230 \text { sn boyunca IV. Smif YYL ( } \lambda=970 \mathrm{~nm}) \\
\text { uygulanmışstr. }\end{array}$ & $\begin{array}{l}- \text {-Hastaların \%61' 'inde Evre III ve üzerinde OM belirlenmiş. } \\
\text { Tedavinin dördüncü günü OM medyanı Evre II'ye düşmüsstür } \\
(p=0,001) \text {. }\end{array}$ & VI \\
\hline
\end{tabular}


Yurdakul $\quad 0 . z$

JCP2018;16(3):51-78

Tablo 2. Devam. Kanserll çocuklarda oral mukozite yönelik kullanıllan kantta dayalı yöntemler

\begin{tabular}{|c|c|c|c|c|c|}
\hline Yazarlar & Araştrrma Türü// Örneklemi & Ölçüm Aracı & Uygulama & Elde edilen sonuç & $\begin{array}{l}\text { Kantt } \\
\text { düzeyi }\end{array}$ \\
\hline & nakli olan hastalar ( $\mathrm{n}=18,10-17$ yas) & & & $\begin{array}{l}\text { - 11. gün kontrolünde Omde tam iyileşme görülmüşstür } \\
\text { (medyan WHO =0, IQR =0-1) } \\
\text {-VAS skoru 1. Gün } 5 \text { iken } 4 \text {. Gün 2ye düşmüștür }(p<0,001) \\
\text {-YYLT’nin OM ağrı ve şiddetinde azalma sağladı̆ı̆ } \\
\text { belirtilmiştir. }\end{array}$ & \\
\hline $\begin{array}{l}\text { Raphael ve } \\
\text { ark. } 2014\end{array}$ & $\begin{array}{l}\text {-Çok merkezli prospektif randomize } \\
\text { kontrollü çift kör çalış̧a } \\
\text {-Standart doz kemoterapi alan ya da } \\
\text { hematopoetik kök hücre nakli olan } \\
\text { hastalar (n=34, 4-18 yaş) }\end{array}$ & $\begin{array}{l}\text {-NCI-CTC } \\
\text {-Yaşa uygun ağrı } \\
\text { skorları }\end{array}$ & $\begin{array}{l}\text {-Kliniğin standart lokal destek tedavisine ek olarak } \\
\text { gruplara } 4 \times 1 \quad \text { Caphasol } \quad(\mathrm{n}=16) \quad \text { veya } \quad \text { sodyum } \\
\text { bikarbonot ile }(\mathrm{n}=18) \text { gargara yaptrrlmıștr. }\end{array}$ & 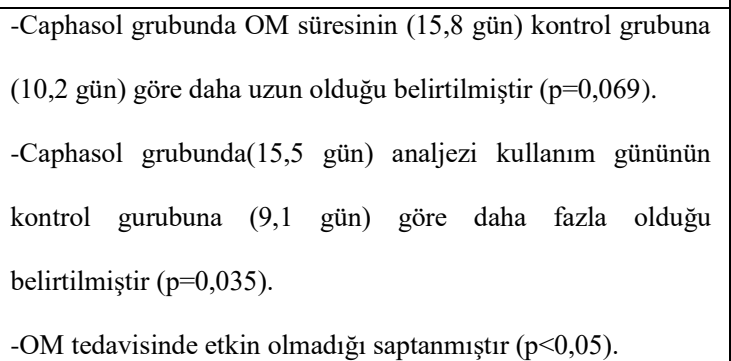 & II \\
\hline
\end{tabular}

AUC: Walsh skala (area-under-the-curve)

ChIMES: Çocuklarda oral mkozit değerlendirme skalası (Children's international mucositis evaluation scale)

DSÖ OM skalası: Dünya Sağllk Örgütu oral mukozit skalas

DYLT: Düşük yoğunluklu lazer tedavisi

NCI-CTC: Ulusal kanser enstütüsüu yaygnn toksisite kriterleri (National cancer institutecommon toxicity criteria)

OAG: Sözel değerlendirme rehberi (Oral assessment guide)

OMAS: Oral mukozit değerlendirme skalası (Oral mucositis assessment scale)

TPN: Total parenteral nutrisyon

VAS: Görsel ağrı skalas

YYLT: Yüksek yoğunluklu lazer tedavisi 


\section{Tartışma}

Kanserli çocuklarda gelişen OM'in önlenmesi ve tedavi edilmesi için kanıta dayalı uygulamaların kullanıldığı çalışmaların sistematik olarak incelendiği bu araştırmada, çalışmaların özellikleri, uygulanan yöntemler ve etkinlikleri değerlendirilmiştir. Kanserli çocuklarda OM insidansı (\%40-100) yüksek olmasına rağmen (13), pediatrik popülasyonda gelişen OM'nin önlenmesi ya da tedavi edilmesi için kullanılan yöntemlerin incelendiği çalışma sayısı oldukça azdır. Çalışmaların büyük çoğunluğunun deneysel çalışma olmaları nedeniyle örneklem büyüklüklerinin 50 ve altı olduğu, veri toplama araçlarının geçerli ve güvenilir olduğu, çalışma randomizasyonlarının yaklaşık yarısının çift körleme ile yapıldığı, çalışmaların büyük çoğunluğunun sonuçlarının açıkça belirtildiği ve örnekleme genellenebilir olduğu görülmektedir.

OM'in önlenmesinde ve tedavisinde pediatrik popülasyona özgü rehber bulunmamaktadır. ONS (2018), "puting evidence into practice" sayfasında çocuk ve erişkinlerde yapılan çalışma sonuçlarını kullanarak mukozit bakımı uygulama önerileri sunmakta ancak çocuklara özgü öneriler yer almamaktadır (14).

DYLT ile ilgili yapılan çalışmalar, DYLT’nin OM iyileşmesini hızlandırdığı $(18,20)$, OM ağrısında azalma $(16,17)$ sağladığını göstermekte nutrisyon desteğine bu sayede ihtiyaç duyulmadığını (17) belirtmektedir. ONS (2018) hematopoetik kök hücre nakli olan hastalar ve baş ve boyun kanseri tanılı hastalarda DYLT'nin oral mukozite yönelik kullanılabileceğini önermektedir. Yaptığımız sistematik inceleme sonuçlarında da DYLT'nin uygulandığı hasta grubunda hematopoetik kök hücre nakli olan hastaların yer aldığı ve yöntemin OM'de etkin olabileceği düşünülmektedir. Benzer şekilde daha yüksek dalga boyu kullanılan bir çalışmada OM'de tam iyileşme görülmüş, OM ağrı ve şiddetinde azalma olduğu belirtilmiştir (48). ONS (2018) bu yöntemi etkin olabilecek yöntemler arasında yer vermesine rağmen, YYLT’nin çocuklarda kullanımı ile ilgili sadece bir çalışma bulunması kullanımı için yeterli kanıt sağlamamaktadır.

İncelenen çalışmalarda, kemoterapinin ilk günü $(22,23)$ ve bir gün öncesinde (24) klorheksindinli gargara kullanan hastalarda OM semptomlarında (22), şiddetinde (23) ve insidansında $(24,25)$ azalma 
olduğunun belirtilmesine rağmen OM şiddetini etkilemediğini (22) gösteren çalışma da mevcuttur. ONS (2018), genel popülasyonda klorheksidinin kullanımını önermemektedir.

Paliferminin OM şiddetinde $(27,28)$ ve parenteral beslenme süresinde (28) azalma sağladığı belirlenmiştir. ONS’a (2018) göre palifermin, kök hücre nakli olan ve yüksek doz kemoterapi alan hastalarda etkin olabilecek yöntemler arasında yer almaktadır. İncelenen araştırmaların kök hücre nakli olan ve yüksek doz kemoterapi alan hastalarda yapılması, paliferminin farklı yaş gruplarında farklı dozlarda karşılaştırıldığı bir başka çalışmada doz toksisitesinin olmadığının belirtilmesi (29) çocuklarda kullanılabileceğini ancak çalışmaların yeterli kanıt sağlamadığını düşündürmektedir.

Kriyoterapinin OM şiddetinde azalma sağladığı (40) ve etkin olmadığına (39) yönelik iki çalışma bulunmaktadır. ONS'un (2018) kriyoterapi uygulamasının genel popülasyonda etkin olduğunu belirtmesine rağmen pediatrik popülasyonda çalışma sayısı yetersiz ve sonuçlar tutarsızdır.

Yapılan çalışmalar sakızın Evre I ve II OM insidansında azalma sağladığını göstermektedir $(41,42)$. ONS'da (2018) yer almamasına rağmen uygulamasının çocuklar için kolay olacağı ve maliyetinin düşük olmasından dolayı randomize kontrollü çalışmalarla desteklenerek etkinliğinin kanıtlanması gerektiği düşünülmektedir.

Balın OM iyileşmesini hızlandırdığı (31), OM şiddetinde azalma sağlayarak (33), enfeksiyonları önlediği (32) belirlenmiştir. Ayrıca antibiyotik kullanımında (33) ve hastanede kalma süresinde azalma (32) sağladığı saptanmıştır. E vitaminin OM üzerinde etkin olduğunu gösteren çalışmaların $(34,35)$ yanı sıra etkin olmadığını gösteren çalışma (36) da bulunmaktadır. Glutaminin OM insidansında, şiddetinde (37) ve enteral beslenme desteğine olan ihtiyaçta (38) azalma sağladığı görülmüştür. Propolis (46) ve rhGM-CSF (47) OM üzerine etkilerinin incelendiği çalışmalarda ise bu yöntemler etkin bulunmamıştır. Çalışma sayılarının yetersiz olması ve ONS'un (2018) bal, E vitamini, glutamin, propolis ve rhGM-CSF'in etkinliğinin kanıtlanamadığını belirtmesi nedeniyle, mevcut kanıtların çocuklarda kullanımı desteklemediği düşünülmektedir.

Tramueel S'in OM semptomlarını azalttığını (43) ve etkin olmadığını (44) gösteren iki çalışmanın sonuçlarının birbirini desteklemediği görülmüştür. Caphasol ile ilgili yapılan çalışma sonucu ise OM üzerinde etkin olmadığını göstermektedir (50). Propolis, Tramueel S ve caphasol uygulamaları ONS'da (2018) etkin olmayan yöntemler arasında yer almaktadır. Literatürde yer alan yöntemlerin 
çoğunun pediatrik popülasyonda kullanımını destekleyecek çalışma sayısının yetersiz olduğu ve kanıt düzeyi yüksek güncel çalışmalara ihtiyaç olduğu düşünülmektedir.

\section{Sonuç}

Literatürde bir çok yöntemin etkinliğini inceleyen çalışmaların olmasına rağmen, kanıt oluşturacak çalışma sayısının az olması ve kanıtların tutarsız olması genelleme yapmayı güçlendirmektedir ve pediatrik onkoloji hastalarının bakımında standart bir OM protokolü oluşturulmasını engellemektedir. Kemoterapi tedavisi alan çocuklarda OM oluşumunun engellenmesi ve tedavisine yönelik rehberlerin oluşturulması ve etkinliği belirlenen ürünlerin kanıt düzeylerini arttıracak genellenebilir çalışmaların yapılması önerilmektedir.

Çıkar çatışması: Yazarlar ya da çalışma sonuçları ile ilgili herhangi bir çıkar çatışması yoktur.

\section{Kaynaklar}

1. Fabricant DS, Farnsworth NR. The value of plants used in traditional medicine for drug discovery. Environ Health Perspect 2001;109:69-75.

2. Resmi Gazete Geleneksel ve Tamamlayıcı Tip Uygulamaları Yönetmeliği, http://www.resmigazete.gov.tr/eskiler/2014/10/20141027.pdf/ Avaliable Date: 1 October 2017

3. Genç RE, Senol S, Turgay AS, Kantar M. Complementary and alternative medicine used by pediatric patients with cancer in western Turkey. Oncol Nurs Forum 2009; 36:159-64.

4. Gözüm S, Arikan D, Büyükavci M. Complementary and alternative medicine use in pediatric oncology patients in eastern Turkey. Cancer Nurs 2007;30(1):38-44.

5. Karalı Y, Demirkaya M, Sevinir B. Use of complementary and alternative medicine in children with cancer: effect on survival. J Pediatr Hematol Oncol 2012;29(4):335-44.

6. Italia S, Wolfenstetter SB, Teuner CM. Patterns of complementary and alternative medicine (CAM) use in children: a systematic review. Eur J Pediatr 2014;173(11):1413-28.

7. National Center for Complemantary and Integrative Health Complementary Alternative, or Integrative Health: What's In a Name?, https://nccih.nih.gov/health/integrative-health/ Avaliable Date: 12 September, 2017 
8. Diorio C, Lam CG, Ladas EJ, Njuguna F, Afungchwi GM, Taromina K, et al. Global use of traditional and complementary medicine in childhood cancer: a systematic review. J Glob Oncol 2017;3:791-800.

9. Öztürk C, Karataş H, Längler A, Schütze T, Bailey R, Zuzak TJ. Complementary and alternative medicine in pediatrics in Turkey. World J Pediatr 2014;10(4):299-305.

10. Koç Z, Tural E, Gudek E. Determining complementary and alternative medicine methods used by paediatric haematology-oncology patients. J Nurs Healthc Chronic Illn 2011;3(4):361-71.

11. Magi T, Kuehni CE, Torchetti L, Wengenroth L, Lüer S, Frei-Erb M. Use of complementary and alternative medicine in children with cancer: a study at a Swiss University Hospital. PLoS One 2015;10(12):1-13.

12. Çavuşoğlu H. Oral mukozit yönetiminde kanıta dayalı hemşirelik. Turkiye Klinikleri J Med Sci 2007;27(3):398-406.

13. Hashemi A, Bahrololoumi Z, Khaksar Y, Saffarzadeh N, Neamatzade H, Foroughi E. Mouthrinses for the prevention of chemotherapy induced oral mucositis in children: a systematic review. Iran J Ped Hematol Oncol 2015;15(2):106-12.

14. Oncology Nursing Society Mucositis Topic, https://www.ons.org/practiceresources/pep/mucositis/ Avaliable Date: 1 October, 2017

15. Fineout-Overholt E, Melnyk BM, Stillwell SB, Williamson KM. Evidence-based practice step by step: critical appraisal of the evidence: part I. Am J Nurs 2010;110(7):47-52.

16. Amadori F, Bardellini E, Conti G, Pedrini N, Schumacher RF, Majorana A. Low-level laser therapy for treatment of chemotherapy-induced oral mucositis in childhood: a randomized double-blind controlled study. Lasers Med Sci 2016;31(6):1231-6.

17. Castro JFL, Abreu EGF, Correia AVL, Mota Vasconcelos Brasil C, Cruz Perez DE,Paula Ramos Pedrosa F. Low-level laser in prevention and treatment of oral mucositis in pediatric patients with acute lymphoblastic leukemia. Photomed Laser Surg 2013;31(12):613-8.

18. Cauwels RG, Martens LC. Low level laser therapy in oral mucositis: a pilot study. Eur Arch Paediatr Dent 2011;12(2):118-23. 
19. Eduardo FP, Bezinelli LM, Carvalho DL, Lopes RM, Fernandes JF, Brumatti M, et al. Oral mucositis in pediatric patients undergoing hematopoietic stem cell transplantation: clinical outcomes in a context of specialized oral care using low-level laser therapy. Pediatr Transplant 2015;19(3):316-25.

20. Kuhn A, Porto FA, Miraglia P, Brunetto AL. Low-level infrared laser therapy in chemotherapy-induced oral mucositis: a randomized placebo-controlled trial in children. J Pediatr Hematol Oncol 2009;31(1):33-7.

21. Silva VCR, Motta Silveira FM, Lima GS, Cruz MMD, Júnior ADFC, Godoy GP. Photodynamic therapy for treatment of oral mucositis: pilot study with pediatric patients undergoing chemotherapy. Photodiagnosis Photodyn Ther 2018;21:115-20.

22. Cheng KK, Chang AM. Palliation of oral mucositis symptoms in pediatric patients treated with cancer chemotherapy. Cancer Nurs 2003;26:476-84.

23. Cheng KK, Chang AM, Yuen MP. Prevention of oral mucositis in pediatric patients treated with chemotherapy: a randomised crossover trial comparing two protocols of oral care. Eur $\mathbf{J}$ Cancer 2004;40:1208-16.

24. Costa EM, Fernandes MZ, Quinder LB, de Souza LB, Pinto LP. Evaluation of an oral preventive protocol in children with acute lymphoblastic leukemia. Pesqui Odontol Bras 2003; 17:147-50.

25. Pinto LP, De Souza LB, Gordón-Núñez MA, Soares RC, de Brito Costa EMM, de Aquino ARL, et al. Prevention of oral lesions in children with acute lymphoblastic leukemia. Int $\mathbf{J}$ Pediatr Otorhinolaryngol 2006;70(11):1847-51.

26. Vadhan-Raj S, Goldberg JD, Perales MA, Berger DP, Brink MR. Clinical applications of palifermin: amelioration of oral mucositis and other potential indications. J Cell Mol Med 2013;17(11):1371-84.

27. Gholizadeh N, Mehdipoor M, Sajadi H, Moosavi MS. Palifermin and hlorhexidine mouthwashes in prevention of chemotherapy-1nduced mucositis in children with acute lymphocytic leukemia: a randomized controlled trial. J Dent 2016;17(4):343-7. 
28. Lauritano D, Petruzzı M, D1 Stasıo D, Lucchese A. Clinical effectiveness of palifermin in prevention and treatment of oral mucositis in children with acute lymphoblastic leukaemia: a case-control study. Int J Dent Oral Sci 2014;6(1):27-30.

29. Morris J, Rudebeck M, Neudorf S, Moore T, Graham M, Aquino V, et al. Safety, pharmacokinetics, and efficacy of palifermin in children and adolescents with acute leukemias undergoing myeloablative therapy and allogeneic hematopoietic stem cell transplantation: a pediatric blood and marrow transplant consortium trial. Biol Blood Marrow Transplant 2016;22(7):1247-56.

30. Vitale KM, Violago L, Cofnas P, Bishop J, Jin Z, Bhatia M, et al. Impact of palifermin on incidence of oral mucositis and healthcare utilization in children undergoing autologous hematopoietic stem cell transplantation for malignant diseases. Pediatr Transplant 2014;18(2):211-6.

31. Abdulrhman M, Samır Elbarbary N, Ahmed Amın D, Saeıd Ebrahım R. Honey and a mixture of honey, beeswax, and olive oil-propolis extract in treatment of chemotherapy-1nduced oral mucositis: a randomized controlled pilot study. J Pediatr Hematol Oncol 2012;29(3):285-92.

32. Al Jaouni SK, Al Muhayawi MS, Hussein A, Elfiki I, Al-Raddadi R, Al Muhayawi SM, et al. Effects of honey on oral mucositis among pediatric cancer patients undergoing chemo/radiotherapy treatment at King Abdulaziz University Hospital in Jeddah. Evid Based Complement Alternat Med 2017; doi: 10.1155/2017/5861024.

33. Bulut HK, Tüfekçi FG. Honey prevents oral mocositis in children undergoing chemotherapy: A quasi-experimental study with a control group. Complement Ther Med 2016;29:132-40.

34. El-Housseiny A, Saleh S, El-Masry A, Allam A. The effectiveness of vitamin" E" in the treatment of oral mucositis in children receiving chemotherapy. J Clin Pediatr Dent 2007;31(3):167-70.

35. Khurana H, Pandey Rk, Saksena Ak, Kumar A. An evaluation of vitamin e and pycnogenol in children suffering from oral mucositis during cancer chemotherapy. Oral Dis 2013;19(5):45664. 
36. Sung L, Tomlınson GA, Greenberg ML, Koren G, Judd P, Ota S, et al. Serial controlled N-of1 trials of topical vitamin $\mathrm{E}$ as prophylaxis for chemotherapy-induced oral mucositis in paediatric patients. Eur J Cancer 2007;43(8):1269-75.

37. Chang YH, Yu MS, Wu KH, Hsu MC, Chiou YH, Wu HP, et al. Effectiveness of parenteral glutamine on methotrexate-induced oral mucositis in children with acute lymphoblastic leukemia. Nutr Cancer 2017;69(5):746-51.

38. Ward E, Smith M, Henderson M, Reid U, Lew1s I, Kinsey S, et al. The effect of high-dose enteral glutamine on the incidence and severity of mucositis in paediatric oncology patients. Eur J Clin Nutr 2009;63(1):134-40.

39. Gori E, Arpinati M, Bonifazi F, Errico A, Mega A, Alberani F, et al.Cryotherapy in the prevention of oral mucositis in patients receiving low-dose methotrexate following myeloablative allogeneic stem cell transplantation: a prospective randomized study of the gruppo Italiano trapianto di midollo osseo nurses group. Bone Marrow Transplant 2007;39(6):347.

40. Sato A, Saisho-Hattori T, Koizumi Y, Minegishi M, Iinuma K, Imaizumi M. Prophylaxis of mucosal toxicity by oral propantheline and cryotherapy in children with malignancies undergoing myeloablative chemo-radiotherapy. Tohoku J Exp Med 2006;210: 315-20.

41. Eghbali A, Taherkhanchi B, Bagheri B, Sedeh BS. Effect of chewing gum on oral mucositis in children undergoing chemotherapy: a randomized controlled study. Iran J Ped Hematol Oncol 2015;6(1):9-14.

42. Gandemer V, Le Deley MC, Dollfus C, Auvrignon A, Bonnaure-Mallet M, Duval M, et al. Multicenter randomized trial of chewing gum for preventing oral mucositis in children receiving chemotherapy. J Pediatr Hematol Oncol 2007;29(2):86-94.

43. Oberbaum M, Yaniv I, Ben-Gal Y, Stein J, Ben-Zvi N, Freedman LS et al. A randomized, controlled clinical trial of the homeopathic medication TRAUMEEL $S$ in the treatment of chemotherapy-induced mucositis in children undergoing stem cell transplantation. Cancer 2001;92:684-90. 
44. Sencer SF, Zhou T, Freedman LS, Ives JA, Chen Z, Wall D, et al. Traumeel S in preventing and treating mucositis in young patients undergoing sct: a report of the children's oncology group. Bone Marrow Transplant 2012;47(11):1409-14.

45. Mujica V, Orrego R, Pérez J, Romero P, Ovalle P, Zúñiga-Hernández J, et al. The role of propolis in oxidative stress and lipid metabolism: a randomized controlled trial. Evid Based Complement Alternat Med 2017;11 pages, Article ID 4272940.

46. Tomaževič T, Jazbec J. A double blind randomised placebo controlled study of propolis (bee glue) effectiveness in the treatment of severe oral mucositis in chemotherapy treated children. Complement Ther Med 2013;21(4):306-12.

47. Eren M, Akyüz C, Yalçın B, Varan A, Kutluk T, Büyükpamukçu M. Çocukluk çağı kanserlerinde kemoterapi ile ilişkili mukozit tedavisinde granülosit makrofaj koloni stimülan faktörün ağız bakımındaki yeri. UHOD 2007;2(17):70-8.

48. Chermetz M, Gobbo M, Ronfani L, Ottaviani G, Zanazzo GA, Verzegnassi F, et al. Class IV laser therapy as treatment for chemotherapy-induced oral mucositis in onco-haematological paediatric patients: a prospective study. Int J Paediatr Dent 2014;24(6):441-9.

49. Quinn B. Efficacy of a supersaturated calcium phosphate oral rinse for the prevention and treatment of oral mucositis in patients receiving high-dose cancer therapy: a review of current data. Eur J Cancer 2013;22:564-79.

50. Raphael MF, Den Boer AM, Kollen W, Mekelenkamp H, Abbınk H, Kaspers L, et al. Caphosol, a therapeutic option in case of cancer therapy-induced oral mucositis in children? Support Care in Cancer 2014;22(1):3-6. 